\title{
Wizerunki Michała \\ Kazimierza Paca - przegląd ikonografii hetmana litewskiego i wojewody wileńskiego
}

DOI: https://doi.org/10.21697/an.7927

ANNA SYLWIA CZYŻ

INSTYTUT HISTORII SZTUKI UKSW

ORCID: 0000-0001-7923-1204

Michał Kazimierz Pac (1624-1682) przez kilkanaście lat należał do najbardziej wpływowych obywateli państwa polsko-litewskiego, a jego życie stanowi absorbujący przykład awansu w hierarchii szlacheckiej, jednego z błyskotliwszych w siedemnasto wiecznej Rzeczpospolitej. Choć zachowały się dość liczne wizerunki Paca, żaden z nich nie doczekał się szczegółowej analizy. Nie zajmowano się też do tej pory zależnościami pomiędzy nimi, a także nie sytuowano ch w kontekście autokreacji czy też etapów życia i dokonań magnata.

Kariera wojskowa, rozpoczęta z poziomu towarzysza w choragwi Albrychta Stanisława Radziwiłła, prowadziła Michała Kazimierza Paca, dzięki sprzyjającym okolicznościom i niewątpliwym talentom żołnierskim, wartką ścieżką przez rotmistrzostwo (1656) ku buławie polnej (1663) i wielkiej litewskiej (1667), a pozycja osiągnięta na polu Marsowym przełożyła się na pozyskanie przez niego urzędów senatorskich. Najpierw było to województwo smoleńskie (1663), następnie kasztelania wileńska (1667) i w końcu województwo wileńskie (1669). Trzeba jednak przyznać, że działalność polityczną Pac prowadził wyjątkowo nieumiejętnie, na co wpływ miały nie tyle braki w edukacji, co przede wszystkim emocje, którym dawał pierwszeństwo przed chłodną kalkulacja, szczególnie w czasach Jana III. Nigdy się też Pac nie ożenił, mimo prób wyswatania go podejmowany i przezrodzine i na dworze królewskim nawetza dzinę, ina dworze królewskim nawet za Sobieskiego, pragnącego w kolejnych odsło ach związać go na stałe z tronem ${ }^{1}$.

Niewielkie, by nie powiedzieć: dramatycznie niskie uposażenie, $z$ jakim przyszły hetman wielki litewski i wojewoda wileński rozpoczynał karierę wojskową przy braku ogłady i wyrobienia ${ }^{3}$ nie mogło

1 K. Bobiatyński, M. Nagielski, Testamenty Michała Kazimerza Paca i Aleksandra Hilarego Potubińskiego Taprem 1675 ran wości", t. 3, 2006, cz. 1, s. 125-143; K. Bobiatyński, Michat Kazimierz Pac - wojewoda wileński, hetman wielki ilitewski. Działalność polityczno-wojskowa,

Warszawa 2008.

Z majątku matki nie otrzymał nic, a ze spadku po ojo wziąz za $22-23$

Michał Kazimierz Pac trafił na dwór Albrychta w wieku 18 lat, wcześniej pozostając przy rodzinie. W jego orszaku odbywał podróże do Warszawy, przynajmniej raz przyglądając się pracom sejmu. Dzięki wsparciu kanclerza krótko studiował też przełożyć się na podjęcie u jej progu przemyślanej kampanii wizerunkowej. Wydaje się, że Michał Kazimierz Pac zatroszczył się o nią po raz pierwszy pomiędzy otrzymaniem buławy polnej i buławy wielkiej, kied to podczas rokoszu Lubomirskiego rozpoczął samodzielną działalność polityczną, występując na sejmikach i uczestnicząc po raz pierwszy, zresztą bez większego powo dzenia, na sejmie w marcu 1665 r.

W tym właśnie czasie Pac zakupił w prestiżowej części Wilna, przy via regia, dwie kamienice, które nastepnie scalił Antoklu, gdzie zorganizowat podmiejska A elzibe Nieco pozniej, bow latach i666siedzibę. Nieco poźniej, bo w latach 16661667 przystacpit do prac związanych z fundacją kościoła pw. św. św. Piotra i Pawła, który był usytuowany obok jego antokolskiego dworu. Swiątynia miała być wotum za odbicie 11 lipca 1660 r. Wilna, okupowanego od pięciu lat przez wojska moskiew-

Hosianum, by już w końcu 1648 r. stać się szeregowy członkiem armil litewskiej. Tamże, s. 25-26. Siedzibe trzymał ostatni z rodu - Ludwik Michał Pac

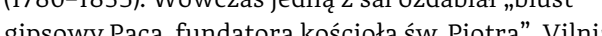
Universiteto Biblioteka f. 4 (A-566)24174 k.19v (Inwentarz z 1813 r.). Takie biusty portretowe powstawały w „ „szkole" rzeźby prowadzonej w latach 1803-1811 na Akademii Wileńskiej (ówczesny Cesars Uniwersytet Wilenski) przez André Le Bruna, dzieło Na marginesie warto takze ws prnieć biust Michała Kazimierza Paca (braz, 1781-1782) Le Bruna, wykonany do galerii sławnych Polaków w Sali Rycerskiej na zamówienie króla Stanisława Augusta, do dzis prezentowany w Zanla Krolewskim w Wrszawie. Ludw testamencie na wystawienie w Warteżamy $w$ Inwalidów gdzie na dziedzińcu miał sie znaleźc poses pieszy brązowy" hetmana. J. Bartyś, Działalność gospodarcza i spoteczna generała Ludwika Paca w dobrach Dowspuda na Suwalszczyznie w latach

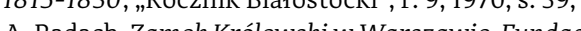
Zbiorówim Sahakian. Rzeźba. Katalog Zbiorów, Warszawa 2011, s. 50-51; K. Mikocka-Rachubowa, André Le Brun „pierwszy rzeźbiarz" Stanistawa Augusta, t. skie, oraz za pomyślne rozbicie konfederacji w wojsku litewskim (1662-1663), co przyniosło Pacowi buławę polną. Uroczystość poświęcenia kamienia węgielnego, w której hetman wziął udział, odbyła się 29 czerwca 1668 r., we wspomnienie św. Piotra i św. Pawła. Ściągnięto na nią specjalnie opłaconych muzyków i zbudowano okolicznościową dekorację. $\mathrm{W}$ tym samym czasie Michał Kazimierz Pac zamówił najpewniej swój pierwszy portret, który znany jest z kopii znajdującej się w mińskim Narodowym Muzeum Sztuki Republiki Białorusi ${ }^{6}$.

Wchodzacy pierwotnie w skład galerii nieświeskiej wizerunek hetmana w półpostaci na ciemnym tle zakomponowano w owalnej, malowanej, złocistej ramie (il. 1). Pac zwrócony jest lekko w prawą stronę. Przedstawiono go w surowym, ale

5 A.S. Czyż, Kościór świętych Piotra i Pawła na Antokolu w Wilnie, Wroctaw-Waszawa-lraków 2008, s. 22-25,

Portret opracowano $\mathrm{w}$ formie noty katalogowej Wi. Pe Kraków 1991, s. 25-26, w której datowano go na lata 70 XVII w. tącząc ewentualnie $z$ wizerunkiem autorstwa Palloniego, wysłanym do Florencii (zob. niżej). Portret Wzmiankowany poźniej w.1. Vaisvilaité, Baroko

XVH a Lieturos portretas, Vilnius 2000, L. 72, 74, M. Matušakaitè, Portretas Lietuvos Didžiojoje Kunigaikštystèje, Vilnius 2010, s. 315. Autorki przypisują płótno Danielowi Schultzowi, datujajc je na czas po 1667 r.Proweniencją obrazu zajęła się Mari Kałamajska-Saeed w artykule Portrety z galerii w: Studia nad sztukg renesansu ibaroku, red. J. Lileyko, I. Rolska-Boruch, t. 5, Lublin 2004, s. 311 . W kontekście galerii hetmanów na zamku w Nieświeżu jednozdaniowo obraz przywołano w: T. Bernatowicz, Mitra ibutawa. Krolewskie ambicie ksiazzat w wztuce Rzeczpo-

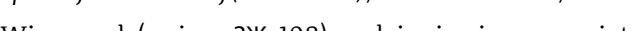
Wizerunek (nr inw. 3ж-108) wydaje się nieco przycię sie domalowany później herb Gozdawa i napis: „MICHAEL CASIMIR(VS) / PAC PALAT[I]N[V]S VI/ LNENSIS SVP(REMVS) / EXERCITVIV]M / M.D.L. DVX. (częsciowo zatarty), a w dolnej partii oznac 


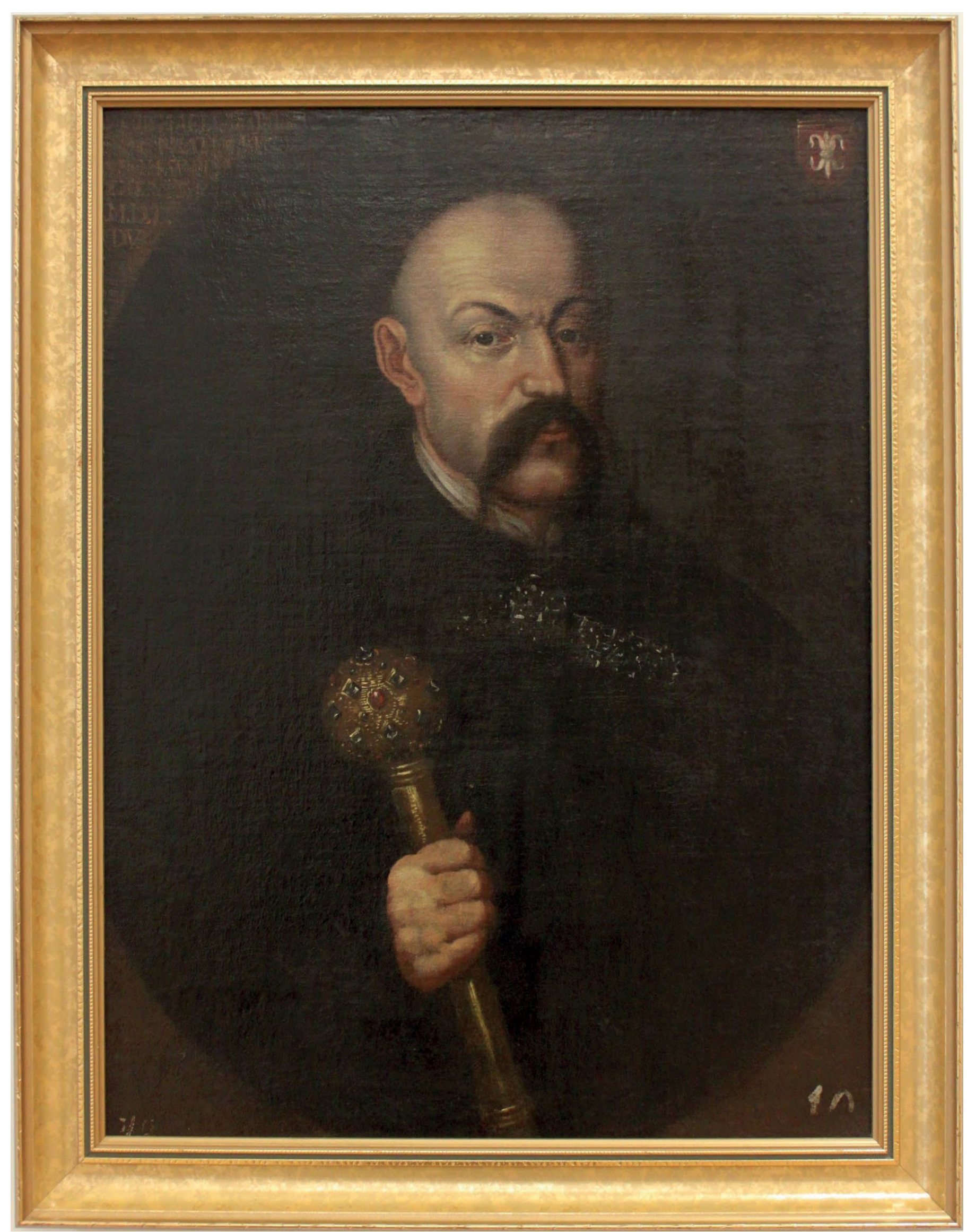

1. Kopia warsztatowa portretu Michała Kazimierza Paca autorstwa najpewniej Daniela Schultza, ok. 1665 r., Mińsk Narodowe Muzeum Sztuki Republiki Białorusi. Fot. M.M. Olszewska

eleganckim, ciemnym stroju, składającym się z żupana z pętlicami, spod którego u szyi widać rąbek kołnierza koszuli, oraz z delil widac rąbek kolnięza koszli, oraz z delii zołyskującą dian modela jest pociągła, szczupła, $\mathrm{z}$ sumiastym opadającymi wąsami i wyraźnie zaznaczonymi ciemnymi brwiami, pomiędzy którymi, nad długim i wąskim nosem widać niewielką, kolistą i nieregularną bliznę. Ciemn włosy są podgolone oraz wysoko i równo obcięte nad czołem i uszami. W prawej, wyciągniętej ku widzowi ręce Michał Kazimierz Pac trzyma złoconą i kameryzowaną buławe (m.in. rubiny, granaty, diamenty).

Sugestywność portretu, którego autor miał wyraźne zacięcie do analizy psychologicznej zdaje się wskazywać, że jest to udana kopia warsztatowa, dla której pierwowzór mógł stanowić konterfekt wykonany przez Daniela Schultza w wersji en pied, odnotowany w nieświeskich zbiorach, zapewne ponownie w wersji warsztatowej repetycjï. Co prawda monografistka malarza, Bożena Steinborn, nie umieściła obrazu w œuvre artysty, ale atrybucję może potwierdzać schemat kompozycyjny powtórzeń związanych z pracownią wtórzeń związanych z pracownią
gdańszczanina, a także białe i szarawe

8 Według Marii Kałamajkkiej-Saeed ciemny kolor stroju to efekt pociemnienia zielonych farb olejnych

zastosowanych w obrazie. Wedfug badaczki fakt ten

ryzatorskim zaciecciem przez Karola Raczyńskiego

przed 1839 r. (Lietuvos mokslu akademijos Vrublevs biblioteka, sygn. A-612). M. Kałamajska-Saeed, Portrety..., dz. cyt., s. 306, 311, 331. Jednak na dziewiętnastowiecznej akwareli Michał Kazimierz Pac ubrany jest w clemnoszary zupan (widoczny bialy kołnier zy o szalowym kołnierzu, spiețą złotą klomrą z czow nym kamieniem (rubin?). Modela przepasano skórzanym pasem o metalowych sprzączkach (il. 2). Bardzo słaba trawestacja portretu z Mińska została zakupion w 2018 r. do zbiorow wilenskkiego Muzeum Nar zadatowano ją na 2. pot. XVII w. Schemat komp płótna, które powstało raczej w XVIII, jeśli nie w XIX wykazuje zbieżność z tzw. Genealogią kodeńska Sapiehów. Zob. https://wwww.valdovurumai.lt/
lankytojams/savaites-eksponatas/2 [dostepp 21 II 2019].

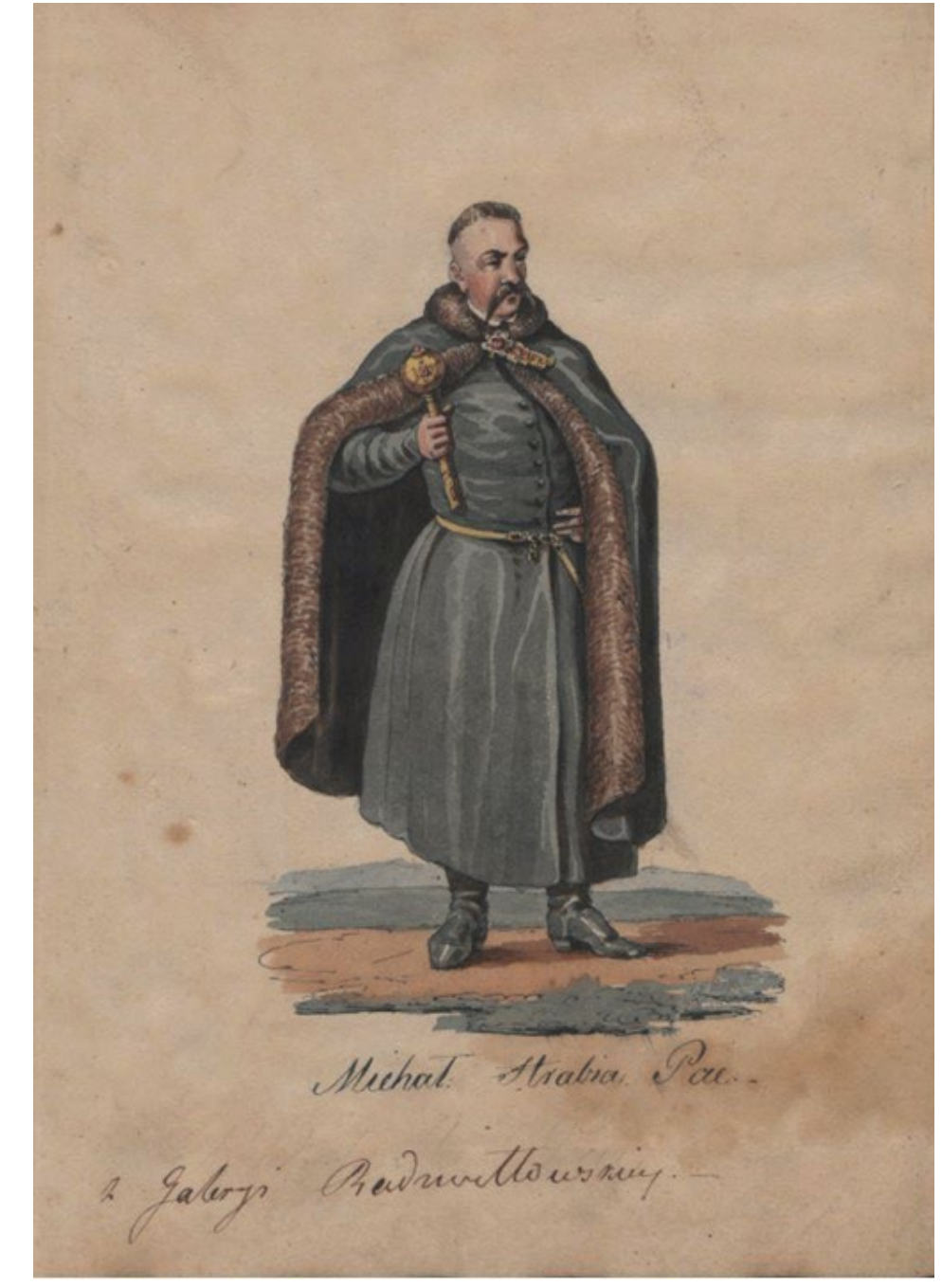

2. Karol Raczyński. Kopia portretu Michała Kazimierza Paca kiej Akademii

laserunki miękko modelujące twarz, przełamane cieplejszymi plamkami barw, co nadaje jej efekt wrażeniowości.

Nieprzypadkowe jest też wyeksponowanie postaci na ciemnym tle światłem nierównomiernie skupionym na twarzy, co podkreśla także impresyjnie malowany pas białego kołnierza. Oświetlona jest również dłoń, w któnej znazk się atrybut najwyż dłon, w której znalazł się atrybut najwyż 
Rzeczpospolitej’. Charakterystyczne dla Schultza, z którego warsztatem do tej por nie łączono tego obrazu, jest też lśnienie szlachetnych kamieni ${ }^{10}$

Ponad czterdziestoletni Michał Kazimierz Pac uchwycony został z poziomymi zmarszczkami na wysokim czole, z lekk nabrzmiałymi powiekami o zmianach chorobowych (włókniaki) i z wyraźnymi bruzdami nosowo-wargowymi (il. 1). Świdrujące spojrzenie ciemnych oczu i zaciśnięte usta, a także zmarszczki, schodzące się przy nasadzie nosa, jednoznacznie wskazują na surową osobowość hetmana, potwierdzoną w licznych źródłach pisanych. Pierwowzór portretu niewątpliwie powstał ad vivum, a wybór artysty nie był przypadkowy. Zadecydowały o tym nie tyle dotychczasowe doświadczenia Schultza w malowaniu elit Rzeczpospolitej, co przede wszystkim fakt, że jego dokonania znał Krzysztof Zygmunt Pac (1621-1684), który w 1670 lub 1671 r. zamówił u artysty własny wizerunek, znany ze zredukowanej kopii, przechowywanej w Nacionalinis M.K. Čiulionio dalle

9 Buławę przed 1675 r. Michał Kazimierz Pac przekaza do sanktuarium maryjnego $\mathrm{w}$ Trokach „obligując [obrazie Najśswiętszej Panny" pozostawała. Niestety, skradziono ją wraz z aplikacjami cudownego obraz w lipcu 1676 r. Z kolei buławę, którą otrzymał w spadku po Wincentym Gosiewskim, przekazał Połubińskiemu zdobiona polecił oddać po swej śmierci podczaszemu litewskiemu Janowi Karolowi Dolskiemu. K. Bobiatynski, M. Nagielski, dz. cyt., s. 140-141; A.S. Czyż, Fundacie artystyczne rodziny Paców. „, Lillium bonae spei at
antiquitate consectarum ", Warszawa 2006, s. 449.

10 Dodaimy dla porzządku, że jest to najsłabszy element 10 Dodajmy dla porzadku,
omawianego portretu.

1 Daniel Schultz wykonał dla Krzysztofa Zygmunta Paca Lownieź portret jego żony Klary lzabelli de Mailly religiinej, z których część znajuuje się do dzis w pokamedulskim kościele w Pożajściu pod Kownem. Był tė̇ zaufanym, goszczącym w pokojach kanclerz
Kazimierza, wywodzący się ze starszej linii rodu, był bowiem nie tylko protektorem hetmana i przywodcą litewskich regalistów, tóry wydatnie wspierał jego z Pacowcji Pacowskiej, ale stanowił też wzór działań niwie sztuki, w tym autokreacji poprzez przemyślane fundacje artystyczne. Omawiany portret, należący do grupy konterfektów hetmańskich, tworzonych w Rzeczpospolitej od początku XVII w., powstał w momencie radykalnej zmiany w społecznym funkcjonowaniu Michała Kazimierza Paca, kiedy ze statysty dalekiego planu stal sie aktywny uczestnikiem wypla tylko wizerunkow do wasnych siedzib, a przede wszystkim do celów urzędowych promowania własnej osoby, do galerii rodowych jego licznych braci i kuzynów oraz ich potomków, a także dla coraz pokaźniejsze klienteli. Popularność Michała Kazimierz Paca znacznie też wzrosła po walkach

z Turkami, które postrzegano w Europie jako zojny w obouro je wińskiej (1676) udowodnił ponadto, że zdolnościami organizacyjno-wojskowymi i odwagą przewyższa sobie współczesnych hetmanów. To wówczas Kosma III Medyceusz posłał m „uno stipo incrostato di pietre e ripieno di medicamenti" ${ }^{\prime 12}$, a trzy lata później wyrazi życzenie, by Michelangelo Palloni wykonał portret Paca do galerii słynnych władców i dowódców prezentowanej w Uffizii ${ }^{13}$.

$$
\text { Nieco wcześniej, niż realizacja pra- }
$$
gnienia, wyrażonego w liście z 9 maja 1679

\section{Krzysztofa Zygmunta Paca - Mikołaja Stefana}

B. Steinhorn, Malorz Daniel Schultz Gdńrsegan

wstużie królów polskich, Warszawa 2004, s. 14,36

124; A.S. Czyż, Fundacie..., dz. cyt., s. 168, 186-189, 240-241, 243, 351, 390 .

12 Archivio di Stato di Firenze, sygn. 4492 LList Lorenza Domenica de' Pazzi do Kosmy III, Kraków 22 II 1676 r.) 3 Zob. także A.s. Czyż, Fundacje..., dz. cyt., s. $302,363$.

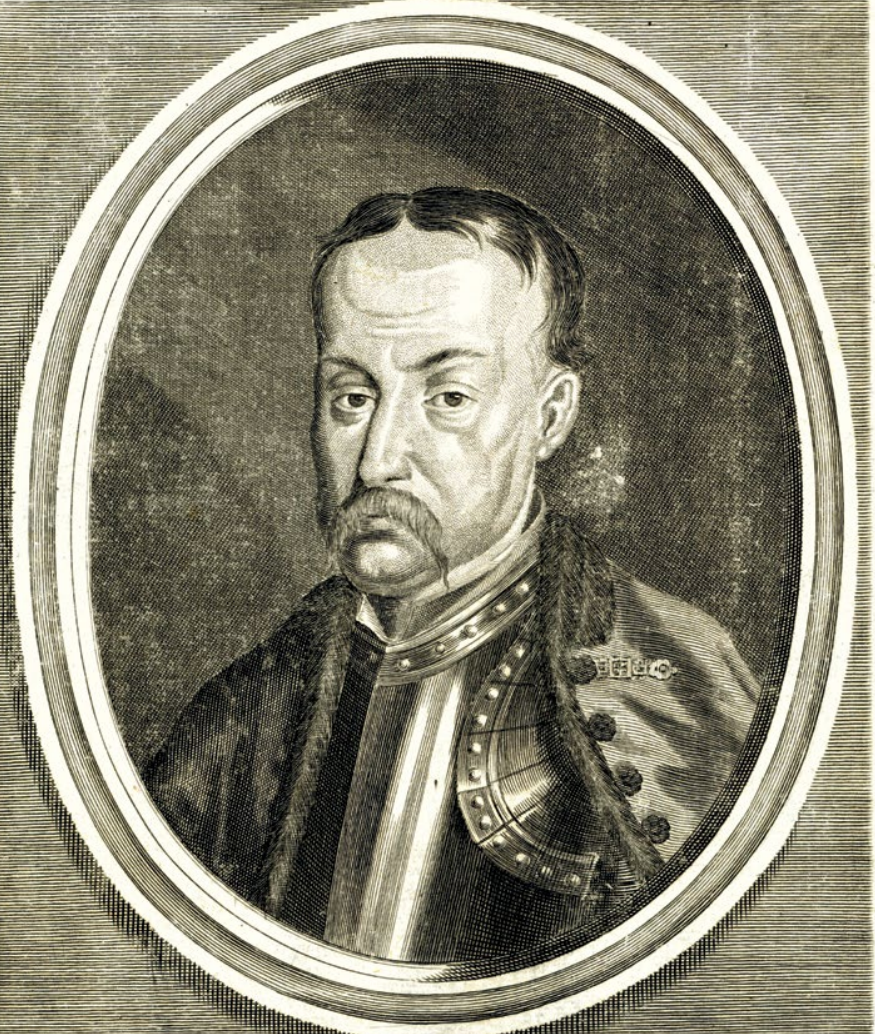

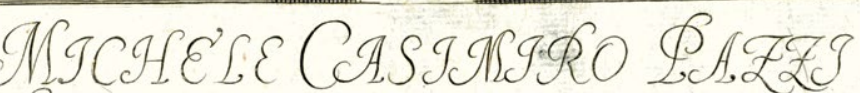

BALATISODJ CIILALA GE=

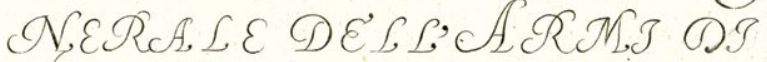

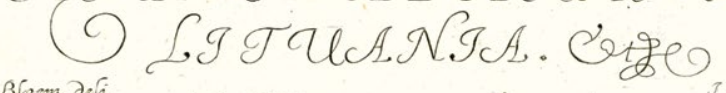
u. 36 cem ze.

do Lorenza Domenica de' Pazzi, dworzanina hetmana i informatora Medyceusza, powsta miedziorytniczy portret Michała Kazimierza Paca (il. 3), który opublikowano w trzecim tomie wydawnictwa Historia di Leopoldo Cesare (Wiedeń 1674) Galeazza Gualda Priorata wraz z wizerunkiem Krzysztofa Zygmunta Paca' zhaj Pacowie ználíli się więc w doborowy. towarzystwie ówczesnych monarchów i przedstawicieli europejskiej elity, do której bezsprzecznie należał przede wszystkim

4 Autorem portretu kanclerza był Johann Franck, który towarzyszyły opisom rokoszu Jerzego Sebastiana Lubomirskiego, walk o buławe litewska po śmierci Pawła Jana Sapiehy oraz konfliktu Paców z Radziwiłami. G.G. Priorato, Historia di Leopoldo Cesare..., t. 3 , Vien. $1674,5.144,633$
Johann Alexander Böner wg rysunku Adriaena van Bloemen ortret Michała Kazimierza Paca z wydawnictwa Historia di Leopoldo Cesare, Vienna 1674. Fot. domena publiczna

kanclerz litewski dzięki swemu pochodzeniu, wykształceniu, majątkowi i posiadanej władzy. Obu krewniaków w identyfikującym podpisie określono jako Pazzich's akentuic prayjnowane bezzastrzeźn pismientic przyjn mo bez zastrzezen wisniennictwie europejskim pokrewieństwo Paców z arystokratycznym rodem florenckim poprzez wspólnego przodka Cosmus Pacciusa' $^{1}$

Omawianą grafikę ukazującą hetmana wykonał Johann Alexander Böner według rysunku Adriaena van Bloemena. Przedstawia ona, zgodnie z konwencją innych portretów z dzieła Priorata, popiersie wojewody wileńskiego w owalnej ramie, zwróconego en trois quarts w lewą stronę ${ }^{17}$. O ile wierność rysów twarzy nie budzi zastrzeżeń, co do sportretowanej osoby, o tyle należy zauważyć niepowtórzoną nigdzie indziej fryzurę modela. Na grafice Bönera Michał Kazimierz Pac ma dłuższe włosy, z przedziałkiem, układającym się nad wysokim czołem w niesforną grzywkę. Strój wojewody, choć inny niż w obrazie z Mińska (zbroja płytowa na żupanie

$15 \mathrm{~W}$ przypadku hetmana brzmi on: „MICHELE CASIMIRO PAZZI / PALATINO DI VILNA GE= / NERAL

16 A.S. Czyż, Fundacje..., dz. cytt., s. 58, 60-61, 64-65. 7 Luźne egzemplarze portretu Michała Kazimierza Paca znajdują się w kilku instytucjach polskich (np. Zakład
zbiorón Ilkonograficznych Bibliotekki Narodowej Zbiorów Ikonograficznych Biblioteki Narodowej, sygn
G.3347, G.6743, G. 28681: Zamek Królewski w Warszawie, nr inw. ZKW 3578; Muzeum Narodowe w Krakowie, sygn. MNK III-ryc.-38012, MNK III-ryc.-38019, MNK III-ryc.-38023; Muzeum Narodowe w Warsz wie, sygn. Gr.Ob.N.1382). Odnotować je można We -ikonograficzne z XVII w., ,Roczniki Muzeum Narodowego", t. 15, 1971 r., nr 2, s. 150; Katalog portretów osobistości polskich iobcych w Polsce działajaccych, red. H. Widacka, t. 4, Warszawa 1994, r. 15; t. 7, Warszawa 1999, s. 7; J.S. Pasierb, M. Janoch
Polonica artystyczne w whiorach watykańshich Warszawa 2002, s. 99-100; M. Matušakaité, dz. cyt s. 282; T. Jakubowski, Grafika. Portrety. Katalog zbiorów. Zamek Królewski w Warszawie - Muzeum, Fundacja Zbiorów im. Ciechanowieckich, Warszawa 
widocznym jedynie w postaci rozchylonego kołnierza, delia podbita futrem o szalowy kołnierzu z pętlicami i metalową klamrą), każe domyślać się nieznanego pierwowzoru istnieniu tego konkretnego przedstawienia, a także innych portretów hetmana w zbroi husarskiej nałożonej na żupan świadczą malowane i graficzne wizerunki Michała Kazimierza Paca z XVIII i XIX w., różniące się detalami stroju i sposobami ujęcia modela. Oczywiście nie mog być one bezpośrednim dowodem na sposób autokreacji hetmana poprzez wizerunki własne, ale ze względu na znikomośc zawłasne, ale ze względ na znikomośc zachowanych zrodel konograficznych z lat 60.-80. XVII w. muszą stac źródłami pośrednimi.

Przede wszystkim należy wskazać n portret znajdujący się w wileński

Lietuvos dailès muziejus ${ }^{19}$ (il. 4). Na walorowo opracowanym brązowym tle zaprezentowano hetmana do kolan, zwracającego się lekko w prawą stronę ku stojącemu na skraju kompozycji stolikowi, na którym znajdue się futrzany kołpak ze szkofią. Wojewoda wileński ubrany jest w bladoniebieski żupan z rękawami, opadającymi na dłoń trójkątnymi łapkami, i z rozchylonym kołnierzykiem ${ }^{20}$, na który nałożono zbroję husarską (folgowy napierśnik z naramiennikami i karwaszami) o złoconych brzegach

8 Grafika stała się wzorem dla niewielkiego, dziewiętnastowiecznego portretu przechowywanego
w Muzeum Narodowym w Warszawie (nr inw 131.085), o czym świadczy sposób upozowania i stró a przede wszystkim wspomniana grzywka i kształt wąsów opadających poniżej brody. Portret publikowany i błędnie datowany na 2. poł. XVII w.: J. Ruszczy-

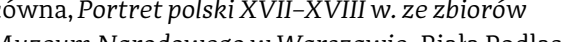
1980 , s. 10 .

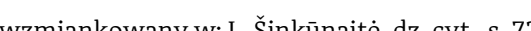
75, gdzie badaczka datuje go na 2. pot. XVII w.
.

20 Kolor kołnierzyka jest inny i do tego dwubarwny (bladobrązowy i biały), co dowodzi późniejszej dataç obrazu. Jaśniejszy kolor jest zapewne echem wystajace 1 los
portretach. i nitach. Na plecy narzucono czerwoną, podbitą futrem delię z szerokim kołniezem, spiętą metalową klamrą z ozdobnym sznureczkami. Lewy rękaw delii nałożono na rękę trzy kiem, gdzie u skórzanego, wąskiego pas znajduje sięs ię szabla (ordynka). W prawej buław

Bez wyrazu, płasko malowany być może na przełomie trzeciej i czwartej ćwierci XVIII w. obraz pochodzi najpewniej z wileńskiego klasztoru kanoników regularnych terańskich, na co wskazuje określenie wojewoly widentylkujacym go napise ja fun dy identyflkjacym go napisie jako fundatora . Po prawejstronie kompozyci mieszczono też herb złożony Michała Kazimierza Paca. w tarczy sercowej znajduje się Gozdawa, a w kolejnych polach Łabędź, Bogoria, Hipocentaurus i Kościesza. W ten sposób zaznaczono jego pokrewieństwo z Szemiotami, Wołłowiczami, Holszańskim Chodkiewiczami22 eksponując także po-

„MICHAE PAC / WOJEW(ODA). WILENSKKI / HET(MAN) Fun(dator) Kan(oników) Jatt( (AA). Litt(t)

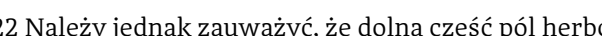

wych została zamieniona W polu 4 zamiast znaku

Halszki z Chodkiewiczów znalazł sie Hipocentaur Aleksandry z Holszańskich (zm. 1551/54). Poza tym swobodnie potraktowano barwy: Gozdawa, Łabędż i Kościesza mają pole niebieskie zamiast czerwone Michała Kazimierza Paca w latach 1667-1669, na co wskazuje tytułowanie go kasztelanem wileńskim (herb uęte literami: „M. K. P. / K. W. / H. W. W. X. L."), W stynne brukselskiej pracowni Jana Leyniersa Pogoń, choć mogto to też być wskazazie litewską Olelkowicz-Stucka, prababkę macierzystą Paca Tapiserie zapisem testamentowym przypadły klasztorowi kanoników regularnych laterańskich. Obecnie znajdują się w Zamku Królewskim w Warszawie - Muzeum (Fundacja Zbiorow im. ClechanowiecNarodowym w Poznaniu (oddział w Gotuchowie) i w wileńskim Lietuvos nacionalinis muziejus. M. Morelowski, Gobeliny wileńskie. Ich pochodzenie, wartość ilosy, Wilno 1933, s. 24-26; Narodziny stolicy.

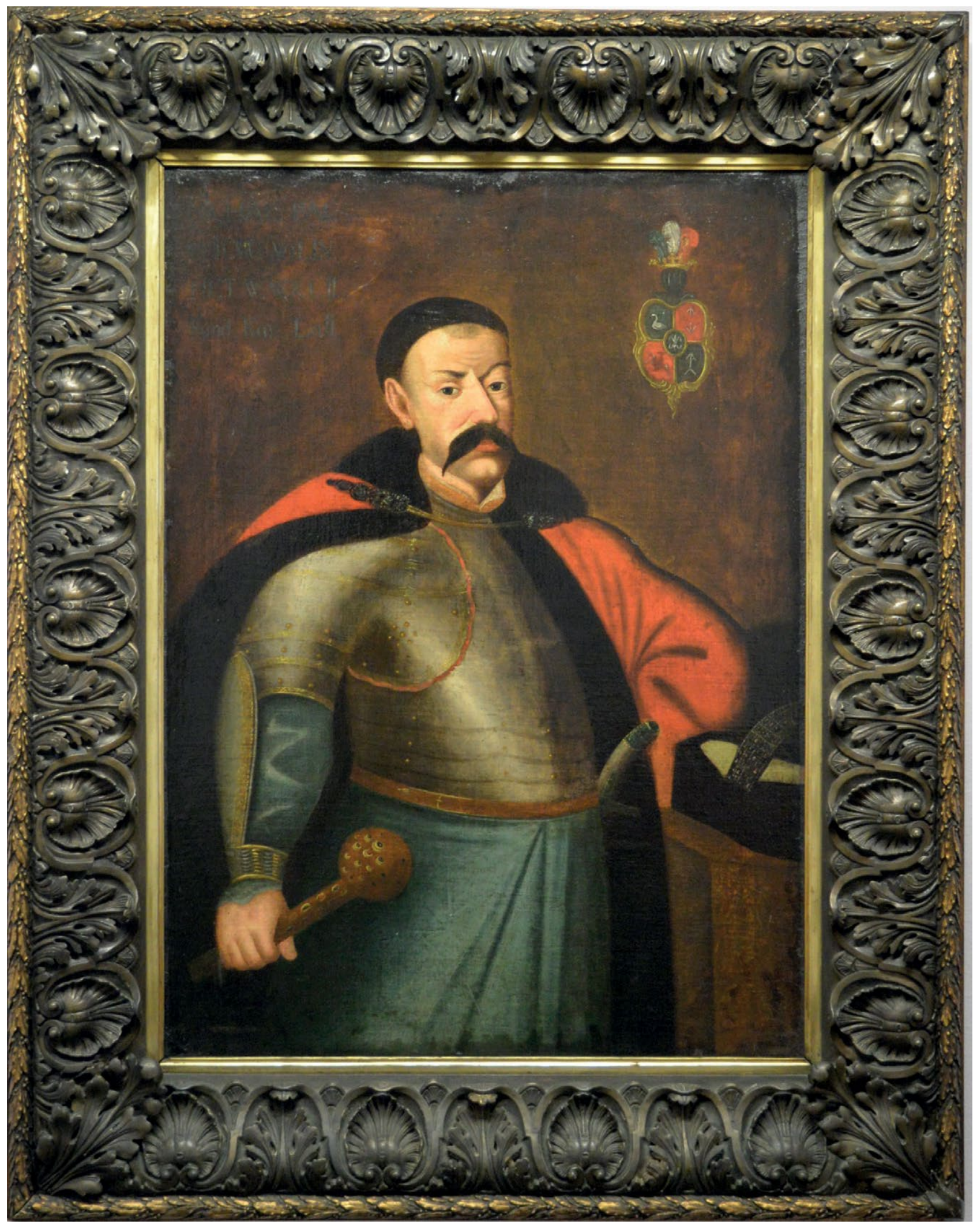

4. Portret Michała Kazimierza Paca, 3-4 ćw. XVIII w.

Wilno, Litewskie Muzeum Sztuki. Fot. A.S. Czyż 
5. Portret Michała Kazimierza Paca, refektarz nowicjatu ezuitów w Wilnie, przed poł. XVIII w. Fot. z archiwum autorki

przez symboliczną interpretację znaków narrację o hetmańskich cnotach czystości mestwa, tak jak to robił za życia sam Mich Kazimierz $\mathrm{Pac}^{23}$. jego osobejest zbroja ibrón przypominajaca o militarnych dokonaniach hetmana ${ }^{24}$. Jeszcze słabszym wizerunkiem Michała Kazimierza Paca z drugiej połowy XVIII w. jest portret znajdujący się w Muzeum Narodowym w Warszawie. Hetmana ukazano w półpostaci w koliście zakomponowanej ramie ${ }^{25}$, ubranego w czerwony żupan, napierśnik z naramiennikam i karwaszami złapciami kolczymi Prawą ręką Pac przyciska do piersi kameryzowan ręką Pac przyciska do piersi kan ryzowan

jasnobrązową delię o szerokim kołnierzu, podbitą czarnym futrem. Na jej prawej pole znajdują się, niespotykane w innych

M. Wrede, Warszawa 1996, s. 255-256; A.S. Czyż, Kościót..., dz. cyt., s. 185; K. Bobiatýnski, M. Nagielssl z. cyt., s. 135

23 B. Paprocki, Gniazdo cnoty, skad herby rycerstwa stawnego [...] poczatek swó́ maja, Kraków 1578, s. 307 1643, s. 4 . O symbolice herbów złożonych Paców zob. A.S. Czyż, Przekaz symboliczny i propagandowy programów heraldycznych w siedemnastowiecznych żałobnych drukach Pacowskich, czyli , „Liliaci” i ich Gozdawa, „Przegląd Wschodni”, t. 14, 2018, z. 4 (56),

24 M. Morka, Polski nowożytny portret konny i jego Gdańsk-Łódź 1986, s. 44

25 Płótno (nr inw. MP 3693) znajdowało się w zbiorach Potockich w Helenowie, a do muzeum trafiło wraz. z portretem Stefana Paca (1587-1640) w 1936 r. jako dar Jakuba Potockiego. Wizerunek hetmana opatrzony jest numerem galeryjnym „224". W zbioprzez skoligacenie z Sapiehami z Wysokich L tewskich. Ksawery Franciszek Sapieha (1807-1882) mąz ostatniej z rodu Ludwiki Pacówny (1819-1895), był przyrodnim bratem Marii Konstancji, matki Jakuba Potockiego $\mathrm{z}$ Helenowa. Na analizowanym portrecie poniżej kartusza, znajduje się napis identyfikujący: W(IELKI). W(IELKIEGO). X(IESTWA) L(TTEWSKIEGO)" Obraz odnotowany i datowany zbyt ogólnie na XVII w.: B. Fabiani, dz. cyt., s. 139, 149; E. Chojecka, Portret polski XVIII i XVIII wieku. Katalog wystawy. Galeria BW. portretach Pacowskich, guzy, a spina ją jubilerska klamra ze sznurkiem.

$$
\text { Podobną konwencję oglądamy na fre- }
$$

J sklepieniu refektarza jezuickiego nowic św. Ignacego w Wilnie ${ }^{26}$ (il. 5) Niestety nie św. Ignacego w Wilnie (il. 5). Niestety nie jest obecnie znany wzorzec, który się nie zachował lub też czeka na swoje odkrycie w muzealnych magazynach ${ }^{27}$ i skarbcach kościelnych. Strój Michała Kazimierza Paca na omawianym fresku w porównaniu

$\mathrm{z}$ portretem $\mathrm{z}$ Lietuvos dailès muziejus (il. 4 ) wzbogacony został o dłuższe sznureczki przy zapięciu delii i szeroki pas tekst or żupana na żółty.

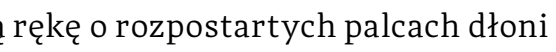
tman ma wyciągniętą, tak jakby brał pod opiekę zakonników zgromadzonych w sali, co zreszta „ „z osobliwej [...] inclinatiej i z dobrego afektu" czynił za życia ${ }^{28}$. Jego postać ujmują chorągwie, przypominając o żołnierskiej posłudze i sławie wyzwoliciela Wilna spod okupacji moskiewskiej ${ }^{29}$. Był bo-

26 Oprócz wizerunku Paca na sklepieniu znajdowały się inne, zktorych zachowały się przedstawienia jezuitów nika Szymona Maffona Rudominy Dusiackiego i męczen-

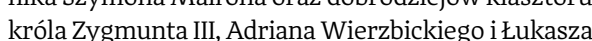
Chodorkowskiego. D. Klajumiené,XVIII a sienu tapyb Lietuvos bažnyčiu architektüroje. Monografija, Vilnius 2004, s. 118-119, 239; M. Matušakaite, dz. cyt., s. 164-170. 27 Przede wszystkim rosyjskich, czego przykładem jest los portretow Pacowskich $\mathrm{z}$ muzeum w Smolensku. N. Mizerniuk, Z dziejow galerî rodowej Lud wika Paca Rzeczpospolitej w XVI-XVIII wieku, red J. Urwanowicz, Białystok 2003, s. 661-678.

28 Michał Kazimierz Pac darował nowiciatowi wileńskiemu swój dwór po Nonhardzie, horodniczym wileńskim, na Antokolu, czyniąc zapisy także dla innych

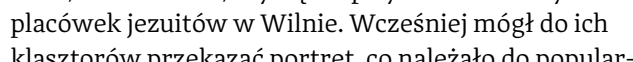
nego ówcześnie zwyyczaju. K. Bobiatyński, M. No dz. cyt., s. 134-136; A.S. Czyż, Kościót..., dz. cyt.,. s. 27.

29 Na skrainych sztandarach znajduje sie stylizowana lili, echo herbu Gozdawa, i napis, cześciowo nieczytelny: „M: D: MICHAEL PAC PALATINUS / VILN(ENSIS): MAGNUS EXERCIT(UUM): / DUX QUA FAVORE QUA

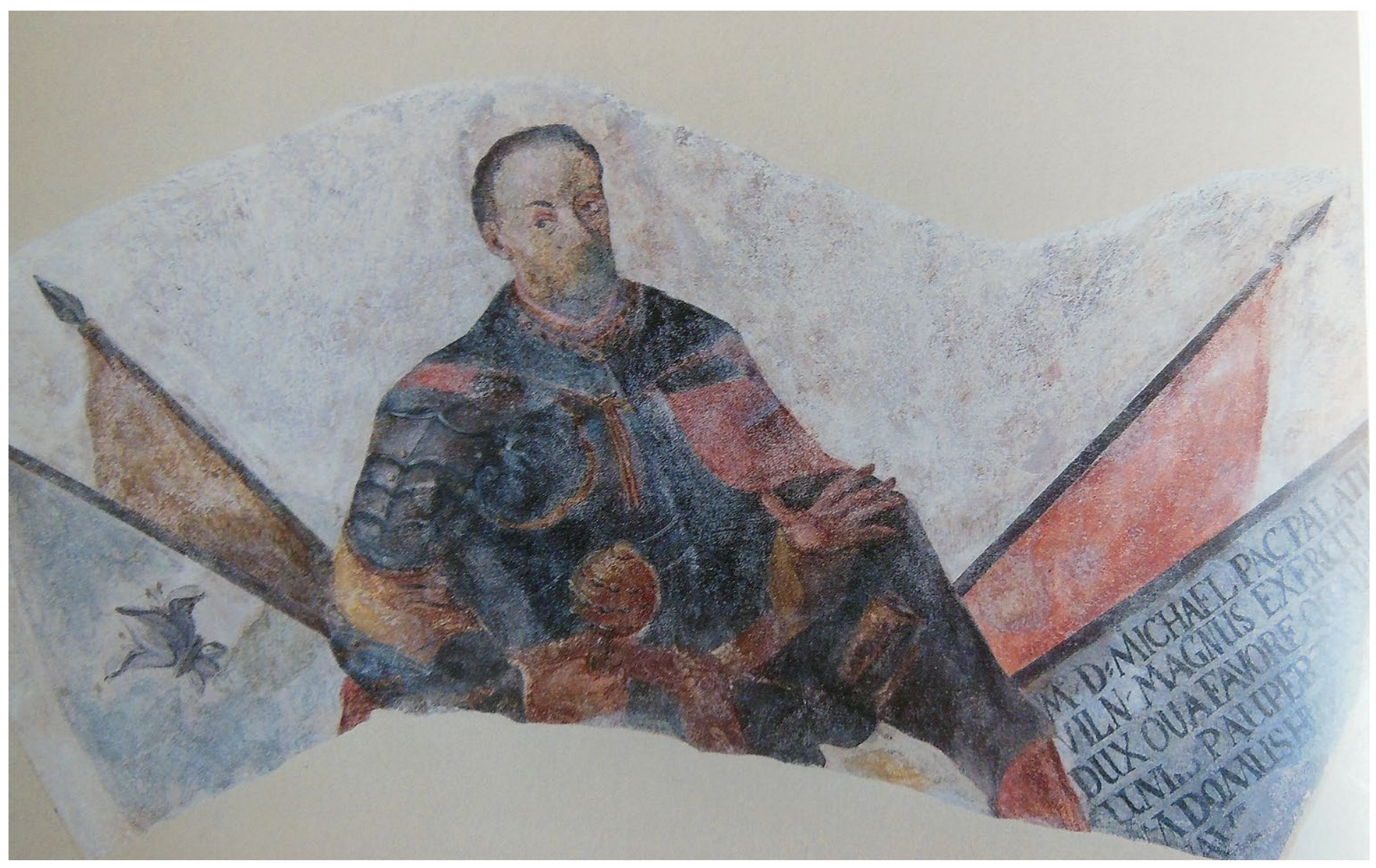

tórego podczas uroczystości pogrzebowych jezuici z A kademii Wileńskiej uhonorowali napisem „Plangit Lithuania patrem" ${ }^{\prime \prime}$. Ten znamienity tytuł o rzymskim pochodzeniu był wykorzystywany przede wszystkim w propagandzie królewskiej, ale odnoszono go także do wybitnych senatorów i hetmanów, w tym Jana Zamoyskiego i Jana Karola Chodkiewicza ${ }^{31}$. Michał Kazimierz Pac topos ojca-opiekuna wykorzystał w wieloznacznej inskrypcji kościoła pw. św. św. Piotra i Pawła na Antokolu, na którego fasadzie kazał wykuć napis: RECINA PACIS / FUNDA NOS IN PACE"

30 A.S. Czyż,Kościót..., dz. cyt., s. 183-184. 31 A. Stankiewicz, Tradycje militarne Chodkiewiczów w swietle grafiki oraz stemmat w drukach ulotnych zstukg wojenng, red. Z Hundert K Żojdź staropolska Oświęcim 2014, s. 76.

32 A. C. Czyż, Kościót. dz. cyt, s. 180-188.
W roli protektora eremitów przedstawił Michała Kazimierza Paca Michelangelo Palloni, malując w kościele w Pożajściu scenę Bolesław Chrobry przekazuje złoto Pięciu Braciom Polskim (il. 6), w której - tak jak we fresku Posłowie u Kazimierza Odnowiciela w klasztorze w Cluny - sportretował rodzinę Paców. Całopostaciowy wizerunek hetmana, który wyciągniętą ręką wskazuje słudze, gdzie złożyć dary dla mnichów, umieszczono z lewej strony kompozycji33.

33 Laima Šinkūnaitè błędnie wskazuje , że portret dz. cyt., s. 106-108). Tymmzasem postá́ z buzdyganem
przzedstawiona na tym fresku może byc ćwentualnie tożsama z Konstantym Władysławem (zm. 1686) chorążym nadwornym i pułkownikiem wojsk litewskich. Aktualizacja z odniesieniem do osób zwizzanych czy to z Krzysztofem Zygmuntem Pacem, pojawia się we freskach pożajskich wielokrotnie Dh Palloniego take rozwiazne byto częte, ocym hetmana znajduje sie $w$ scenie Postowie u Kazimierza 

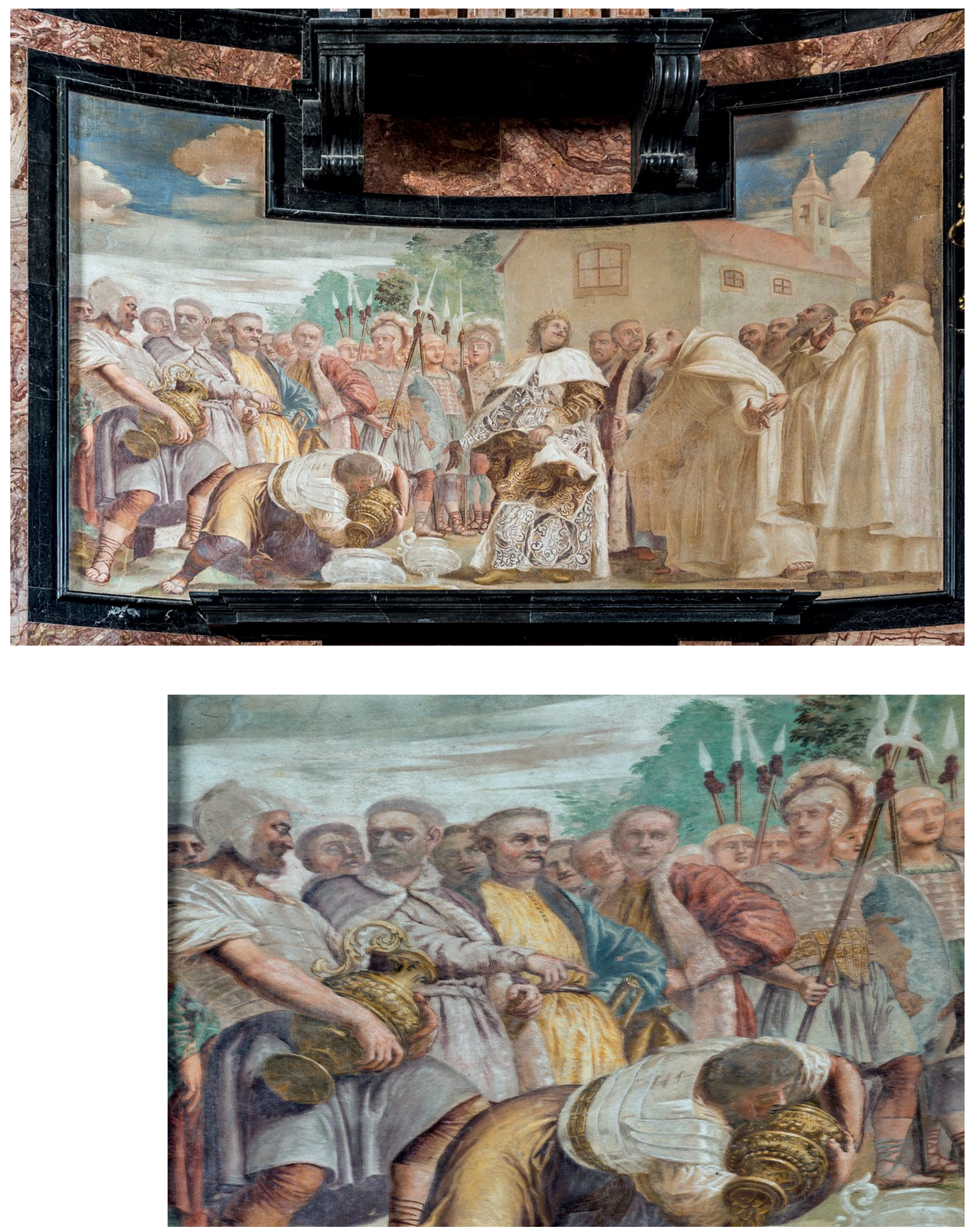

6-7. Michelangelo Palloni, Bolesław Chrobry przekazuje złoto Pięciu Braciom Polskim z portretami Michała Kazimierza Paca i Michała Korybuta Wiśniowieckiego całość i fragment, kościół w Pożajściu, 1680-1685. Fot. N. Piwowarczyk

Spośród świeckich biorących udział w wydarzeniu, tylko ci dwaj poprzez gesty indico i perspicuitatem illustrat, budują narracje iperpicta wem illo Michal Kazimierz Paci Michat Korybut Michat Kazimierz Paci Michat Wiśniowiecki, którego przedstawiono w roli Bolesława Chrobrego. Był to czas, kiedy król - opiekun kamedułów na warszawskich Bielanach, już nie żył, a hetman był w podeszłym wieku. Jednak malarz obu ukazał w pełni sił, akcentując opiekę monarchy nad kamedułami oraz hojność hetmana wobec Kościoła. Wojewoda wileński, o delikatniej niż zazwyczaj potraktowanych rysach twarzy, ubrany jest w obszerny, bladofioletowy żupan i w nieco ciemniejszą podbitą białym futrem delię spiętą niewielkim guzem (il. 7). Do tekstylnego pasa przy lewym boku przywieszona jes szabla o złoconej rękojeścis

Podobnie wygładzone rysy twarzy i taką samą stylizację ubioru, co w refektarzu jezuickiego nowicjatu, widzimy na wizerunku ze zbiorów Muzeum Narodowego w Warszawie, który mógł pierwotnie w Whodzić w skład galerii sławnych Polaków, jaką dla Wileńskiego

Polaków, jaką dla Wileńskiego Towarzystwa Nauk zgromadził do
ks. Józef Konstanty Bogusławski ${ }^{35}$. Zastanawia podobieństwo do tego portretu

świadczy m.in. sportretowanie Kazimierza Jana Sapiehy i biskupa Konstantego Brzostowskiego wry katedre wiln Fundacje..., dz. cyt., s. 366 . O freskach Palloniego w kontekście portretów możnowładczych wspomniała także Marija Matušakaité, która jednak nie podjęła się identyfikacij przedstawionych postaci. M. Matušs-

$34 \mathrm{~W}$ swoim testamencie hetman wymienił ,szable w złoto, srebro i w polor oprawne". Jedną z nich ,złotą zapisał Krzyszztofowi Zygmuntowi Pacowi a druga „we złoto oprawną" Piotrowi Rudominie Dusiackiemu, staroście starodubowskiemu. K. Bobiatyński, M. Nagielski, dz. cyt., s. 140-141.

5 Nr inw. MP 3634. Informacje o obrazie pochodzą wizerunku Michała Kazimierza Paca, utrwalonego w drzeworycie sztorcowym przez Bronisława Puca w 1883 r ${ }^{36}$ (il. 8) Przedstawienie to jest o tyle ciekawe, ze miało być graficzną redakcją malowanego konterfektu, znajdującego się wówczas w kolekcji Czartoryskich.

Z wileńskiego klasztoru kanoników regularnych laterańskich pochodził również wizerunek znany obecnie $\mathrm{z}$ fotografii przechowywanej w Fototece Uniwersytetu Jagiellońskiego ${ }^{37}$ (il. 9). Stanowił on część galerii fundatorów prowinciji litewskiej. z której do dziś zachowały się portrety: Kazimierza Lwa Sapiehy (Strim) Mik: Kazimierza Lwa Sapiehy (stonim), Mikołaja Wolskiega (Krzenienica) i Jana Karola Chodkewicza (Bychów). Wizerunki powstały u schyłku XVII w. ${ }^{36}$ i zostały ujednolicone owalnym formatem (ok. $102 \times 78 \mathrm{~cm}$ )

36 Rycina została dołączona do ksiazżki: J. Łoski Jan Sobieski, jego rodzina, towarzyszze bronii iwspótccesne zabytki, Warszawa 1883, s. 40. Zob. także Katalog..., dz.cyt., t. 4, s. 15, t.7, s. 7 .

37 Fotografia (sygn. OTPK39) powstała przed 1939 38 Portrety, znajdujące się $\mathrm{w}$ wileńskim Lietuvos nacionalinis muziejus (konterfekty Chodkiewicza
i Sapiehy) i w moskiewskim Państwowym Muzer Historycznym (portret Wolskiego) Maria Kazeun ska-Saeed interpretowała jako pochodzace z klasztoru kanoników regularnych laterańskich na Antokolu. Były one odpowiednikiem galerii fundatorów $z$ końca XVII w., do dziś znajdującej się w kazimierskim klasztorze Bożego Ciała. Wizerunki kazimierskie ukazano w ujecciu całopostaciowym przy stoliku $z$ atrybutami i szeroką banderolą ze stosownym podpisem. O ile całość kompozycii w przypadku znanej ikonografii Michała Kazimierza Paca nie znajduje odpowiednika, o tyle twarz hetmana wykazuje największe podobieństwo do grafiki
Aleksandra Tarasewicza (zob. niżej).Katalog zabythów sztuki w Polsce, t. 4: Miasto Kraków, cz. 4. Kazimierz istradom. Kościoły iklasztory, 1, red. I. RejduchSamkowa, J. Samek, Warszawa 1987, s. 78; M. Kałamajska-Saeed, Genealogia przez obrazy. Barokowa ikonografia rodu Sapiehow na tle staropol-
skich galerii ortretowych, Warszaw N. Mizerniuk-Rotkiewicz, Muzeum Starożytności w Wilnie. Historia i rekonstrukcja zbiorów malarstwa igrafiki, Warszawa-Toruń 2016, s. 117-121 (datuje błędnie portrety z klasztoru na Antokolu na l. poł. 


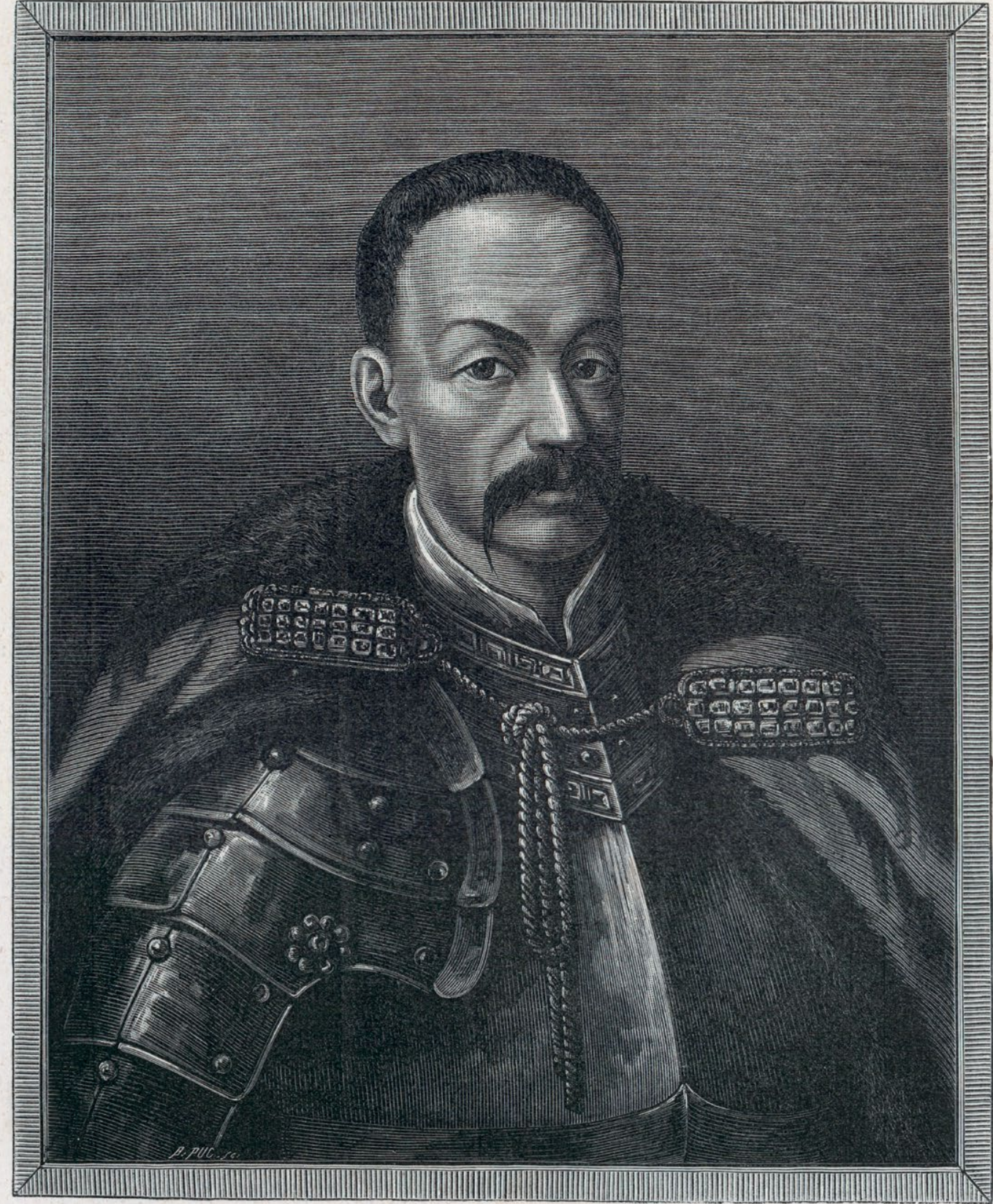

MICHAE PAC

WOJEWODA WILEŃSKI, HETMAN WIELKI LITEWSKI.

WEDEUG PORTRETU BĘDĄCEGO W MUZEUM $X . X$. CZARTORYSKICH W KRAKOWIE.

8. Bronisław Puc, Portret Michała Kazimierza Paca, umieszczony

w ksiż̇ce I. Łoskiego Jan Sobieski, jego rodzina, towarzysze broni

i wspótczesne zabytki, Warszawa 1883. Fot. Polona oraz kompozycją: półpostać na neutralnym tle, gdzie mieści się herb, w otoku, na złotym tle napis identyfikujący, wskazujący na fundacje.

Na archiwalnej fotografii portret Michała Kazimierza Paca uchwycono dość wyraźnie: przedstawiono go w półpostaci, z buławą w prawej, wspartej o stolik ręce. Można też zauważyć, że hetman jest ubrany w zbroję husarską (folgowy napierśnik, karwasze) na żupanie, z wystającym kołnierzykiem koszuli. Na plecy ma narzuconą podbitą futrem delię z szerokim kołnierzem. Spięto ją jednak inaczej niż w wizezem. Spie to ja jedn z inaczej niz w wizeculcy też wilenskiego nowicjatu jezuitow (in bo kameryzowaną klamrą z czapragą. Dokładnie takie zapięcie futrzanej delii uchwycono na grafice autorstwa

Aleksandra Tarasewicza, którą dołączono, dzięki funduszom hetmańskiego brata i testatora, biskupa żmudzkiego Kazimierza (zm. 1695), do drukowanego kazania Adama

Małachowskiego, które duchowny wygłosił podczas rocznicowych egzekwi za do podczas roczicowych egzekwil za duse Melcha Kazimierza Paca w 1686 ro Hetman prezentuje się w polpostaci w liliowym owalnym wiencu, gdy zwraca się lekk w prawą stronę. Ubrany jest w zupan o szerokich rękawach, na który nałożono zbroję

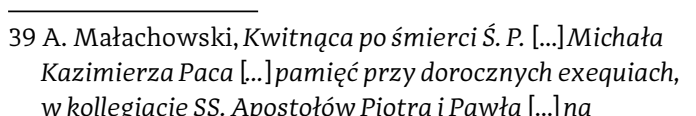
Antokolu..., Wilno 1686, s. 2. Rycinę, bez wieńca i panoplii otaczających postać Michała Kazimierza
Paca, opublikowano w: Katalog..., dz. cyt., t. 4, s. 15-16; Paca, opublikowano w: Katalog..., dz. cyt.t. . . 4, s.1 15-16;
t. 7, s. 15 i wzmiankowano w: I . Talbierska, Grafika XVII wiehu w Polse Fun Warszawa 2011, s. 196, 362. Egzemplarze drukuz miedziorytem znajduja się w Bibliotece Narodowe (sygn. XVII.3.15545, tu także luzem przechowywana karta sygn. G.419/Sz.6), Bibliotece Zakładu Narodowego im. Ossolinskich (sygn. XVII-6488--III) i w Egzemplarze grafiki znajduia sie pona to w Muzeun Narodowym w Krakowie (sygn. MNK III-ryc.-38025) i w Warszawie (sygn. Gr.Pol 12845). Zob. także A.S. Czyż, Koóciót..., s. 191-192; taż, Przekaz..., dz. cyt.

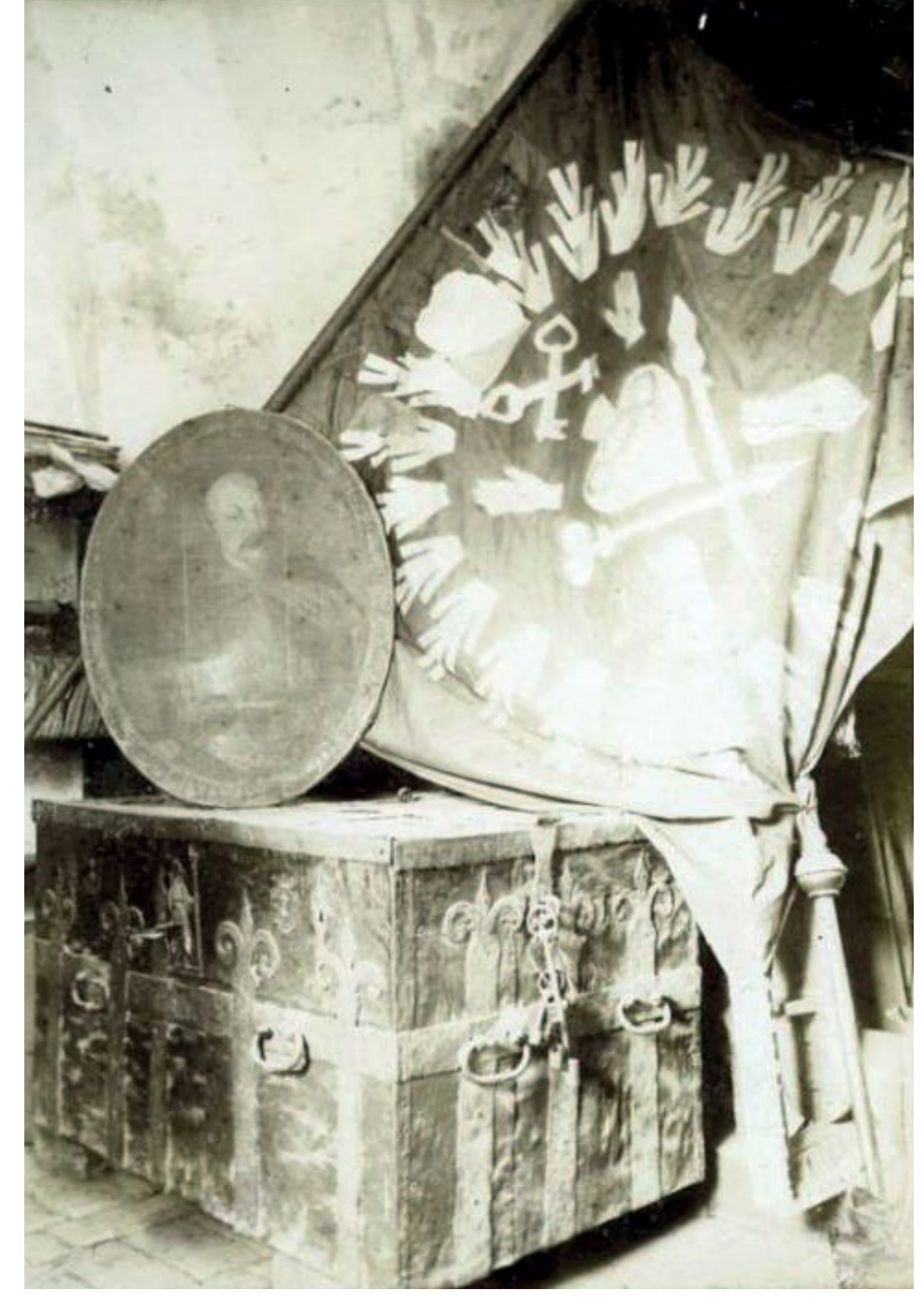

9. Skarbiec kościoła pw. św. św. Piotra i Pawła na Antokolu przed 1939 r. Fot. Fototeka U]

husarską (folgowy napierśnik, karwasz o kolczych osłonach dłoni). Lewą rękę Michał Kazimierz Pac opiera o szablę, a w prawej, wspartej o fragmentarycznie widoczny stolik, trzyma buławę. Rysy twarzy hetmana są wyostrzone, wyraźnie zaznaczono też zmarszczki, zbiegające się nad nasadą nosa. Wydaje sie że zaginiony portret hetmana z klasztoru św. św. Piotra i Pawła na Antokolu oraz wizerunek autorstwa 


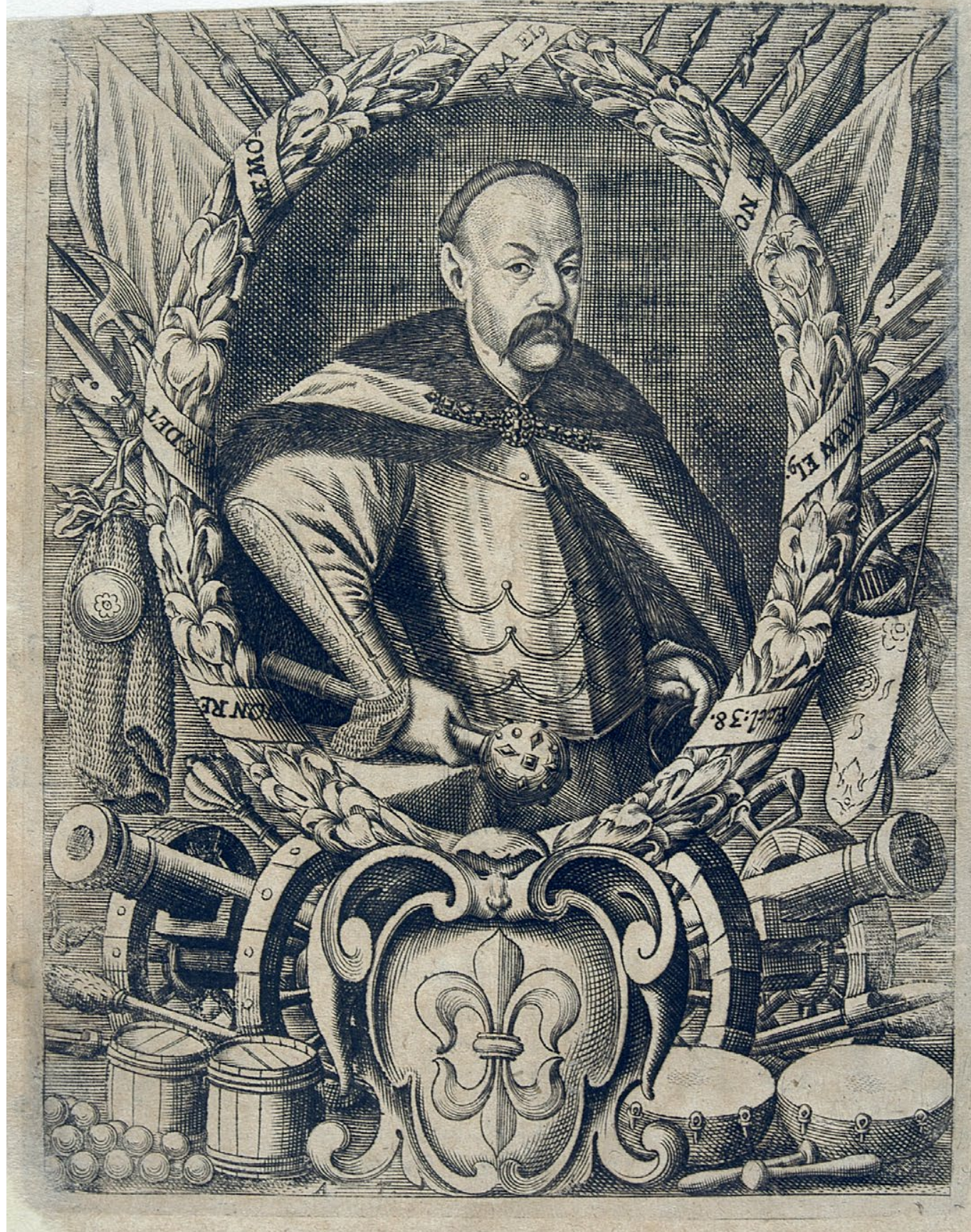

$$
\begin{aligned}
& \text { Paca, rycina dołączona do druku Kwitnaca po śmierci Ś. P. [...] } \\
& \text { Michała Kazimierza Paca [...] pamięć przy dorocznych exequiach, } \\
& \text { w kollegiacie SS. Apostołów Piotra i Pawła [...] na Antokolu..., } \\
& \text { Wilno 1686. Fot. BN }
\end{aligned}
$$

Aleksandra Tarasewicza są od siebie zależne, na co wskazuje kompozycja, strój,

a przede wszystkim sposób scharakteryzowania twarzy hetmana Inaczejednakutożono buławe w rẹku, która na malowanym portrecie jest uniesiona ku górze.

O ile dotychczasowe wizerunk

Michała Kazimierza Paca, nawet jeśli powstały w XVIII w., mieściły się w tradycji przedstawiania osób sprawujących urząd hetmański, o tyle portret graficzny nawiązywał do zwyczaju zapoczątkowanego w Wielkim Księstwie Litewskim przez wasztelana wileńskiego Janusza Radziwit (po 1609). Jednak choć kolejne graficze portrety wodzów litewskich okazale prezentowały swoich modeli ${ }^{40}$, to dopiero w pacowskim miedziorycie z $1686 \mathrm{r}$. w pet ni wykorzystano aluzje związane $\mathrm{z}$ herbem. Michała Kazimierza Paca nie ukazan w wieńcu laurowym, ale, jak wspomniano, w utworzonym z liści i kwiatów lilii, oplecionym wstęga z napisem zaczerpniętym z Pisma Swiętego: Non recedent memoria i(us) et nomen i(us) Eccl(esiatstcus): . tącząc tresć inskrypcjiz symboliką ko a wieńca, wskazano na wieczną chwałe mienia pacowskiego, osiągniętą dzięki sukcesom militarnym, o czym przypominają panoplia spięte w dolnej części na osi z herbem Gozdawa niby jubilerskim klejnotem. Szczególnym i niezbywalnym prawem do niej było wyzwolenie Wilna z pięcioletniej okupacji moskiewskiej,

a wieczną chwałę zapowiadał już sam

herb, którym legitymował się hetman litewski, bowiem:

Symbolizuje ten kwiat; kandor, męstwo sławę

Cnych dzieł i spraw Pacowskich szeroką żuławę:

40 Przykłłady grafik zob. J. Liškevičiené, Mundus emblematum: XVII a. Villiaus spaudiniu ilustracijos,
Którzy Bogu, Królom swym, Ojczyźnie swą

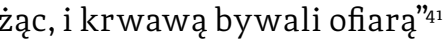
Motyw walki z wrogami Ojczyzny i Kościoła w kontekście Michała Kazimierza Paca, z rozmysłem kreującego się nie tylko na pater patriae, ale i na miles Christianus, pojawia się w obrazie z 1691 r. ${ }^{42}$ Zajmuje on wyjątkowe miejsce wśród wizerunków wo jewody wileńskiego (il. 11). Znacznych rozmiarów płótno, w którym udatnie wykorzystano malarskie rozwiązania (walorowe przejścia i bliki), wisi w kościele pw. św. św. PiotraiPaw zolram i Pawla na Antokolu w Wilnie, mauzelowe przedstawienie, gdzie wojewodę wileńs go, wyraźnie starszego niż na portrecie z muzeum w Mińsku, pokazano z lewą ręką wspartą pod bokiem, prawą zaś z kameryzowaną buławą opartą o stolik. W tle namalowany został zamek z wieżami, przed którym toczy się dynamicznie przedstawiona walka pomiędzy konnymi oddziałami Rzeczpospolitej a wojskami tureckimi. Wagę kompozycji podkrés su zajmująca górną część obrazu.

Michał Kazimierz Pac ubrany jest w bladoróżowy, długi żupan o niskim kołnierzyku i szerokich, mocno marszczonych rękawach oraz w napierśnik husarski z naramiennikami o złoconych nitach, przewiązany w talii sznurem z chwostem, do którego podwiązano u lewego boku szablę

41 Cytat jest dedykacią dla Michała Kazimierza Paca

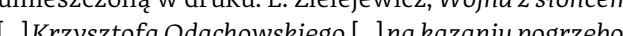
wym, [b.m.w.] [1663], s. 1. Więcej na temat symboliki Gozdawy zob. przywołane wyżej publikacje autorki. 42 Data wykonana czarną farbą znajduje się w lewym dolnymm rogu kompozycji. Tuż obok widnieje napis „fecit", niestety dalsza jego część jest nieczytelna. Obraz jest poczerniaaty i zabrudzony, a czéściowo odnotowany w: L. Šinkūnaitè, dz. cytt. s. 46: M. Matušakaite, dz. cyt., s. 288, 291-292. O Michale Kazimierzu Pacu w kontekście wyobrażenia miles Christianus zob. A.S. Czyż, Kościót..., dz. cyt. 


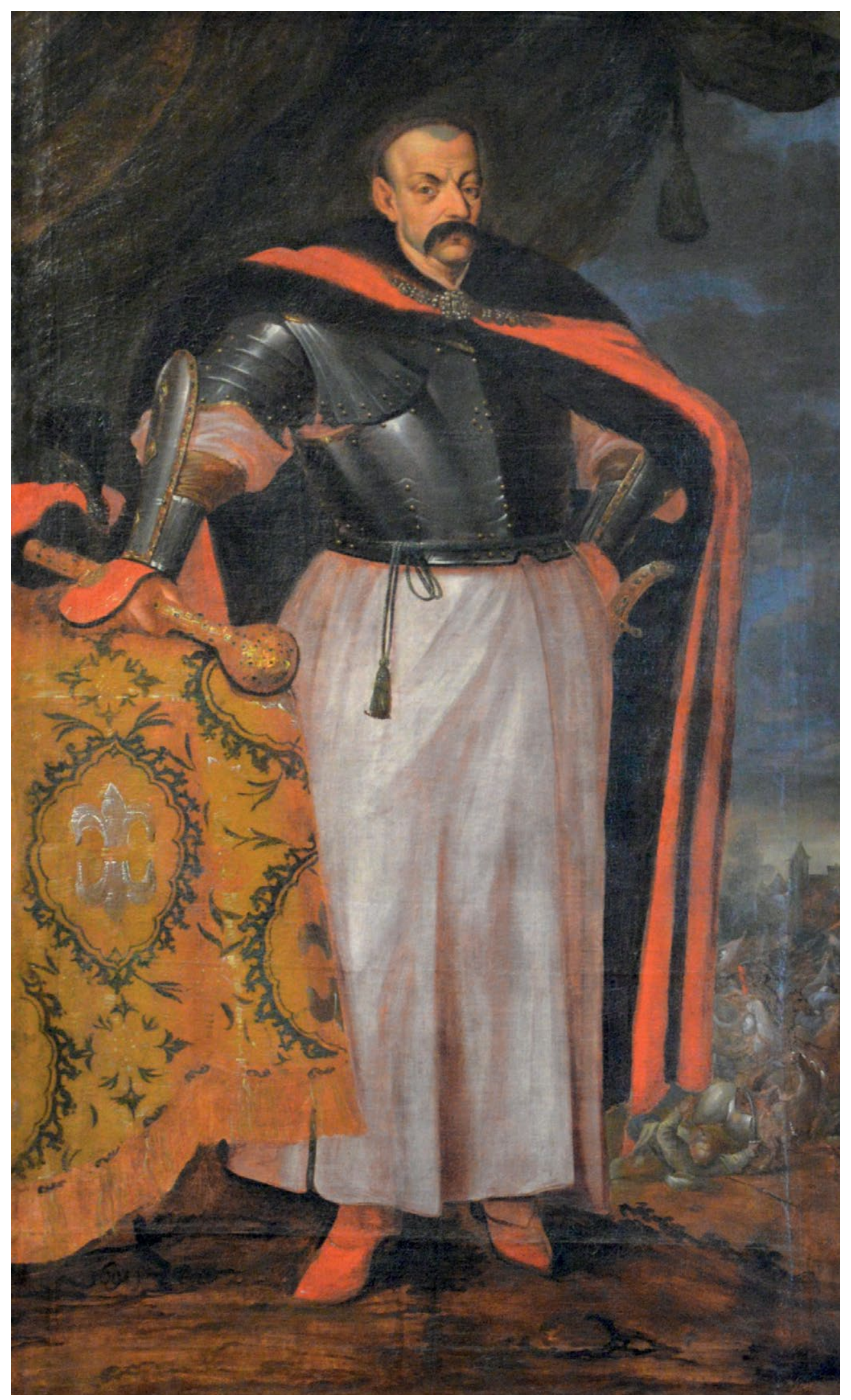

11. Portret Michała Kazimierza Paca, 1691 r

kościół pw. św. św. Piotra i Pawła na Antokolu w Wilnie.

Fot. A.S. Czyż

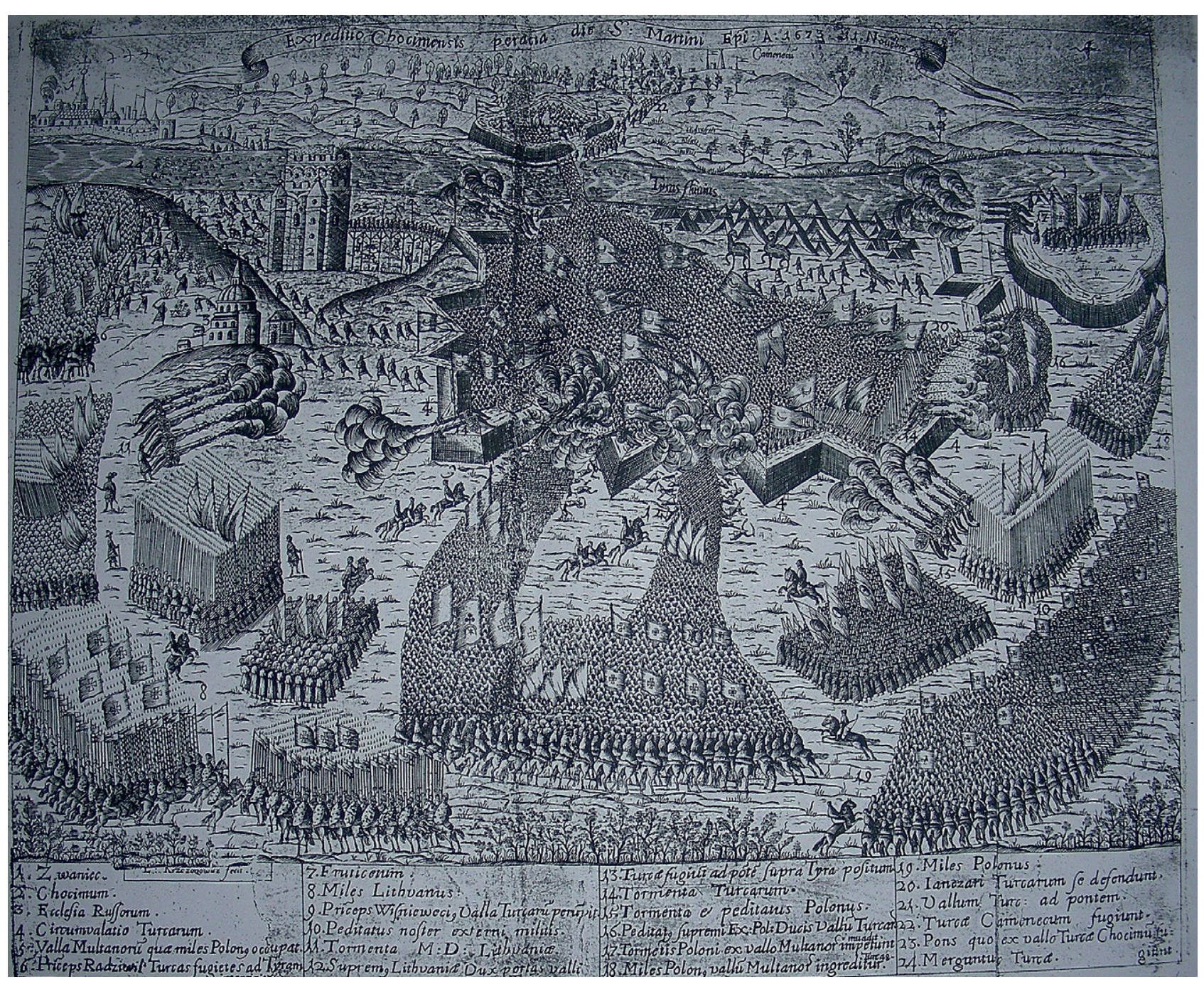

12. Bitwa pod Chocimiem, dołączona do wydawnictwa Virtus dexterae domini

in virtute Polonorum Lituanorumq(ue) ostensa atque illustrissimo [...] Michaeli Casimiro

Pac [...] et illustrissimo ac excellentissimo [...] Michaeli Casimiro Radziwit..., Wilno 1674.

Fot. Biblioteka Uniwersytecka wr Wilnie

o kameryzowanej rękojeści. Karawasze o złoconych nitach, brzegach i ozdobnych aplikacjach mają skórzane i barwione na czerwono łapcie. Podbita futrem delia o szerokim kołnierzu spięta kameryzowaną klamrą jest znana z zaginionego obrazu z klasztoru antokolskiego i grafiki

Aleksandra Tarasewicza. Strój uzupełniają Aleksandra Tarasewicza. Strój uzupełniają zerwone buty i czerwony kołpak o futrzanym otoku ze szkofią z piórami, leżący ną stoliku nakrytym złotą tkaniną z mo wem godła herbowego Gozdawy.
Tkanina jest ciekawym elementem portretu z Antokola, bowiem przypomina brokat, a jego głównym elementem dekoracyjnym jest srebrna Gozdawa w nieregularnych roślinnych wieńcach. Nie jest to przypadkowy deseń, ale integralna część tkaniny, o czym świadczy powtarzalność motywui jego obecność także na zalamaniach i całamanie z logiką malarskiej iluzil. Wydaje sie zie z logika malarskiej lluzji. Wydaje się, ze Michał Kazimierz Pac posiadał tego typu wyrób, charakterystyczny dla kultury 

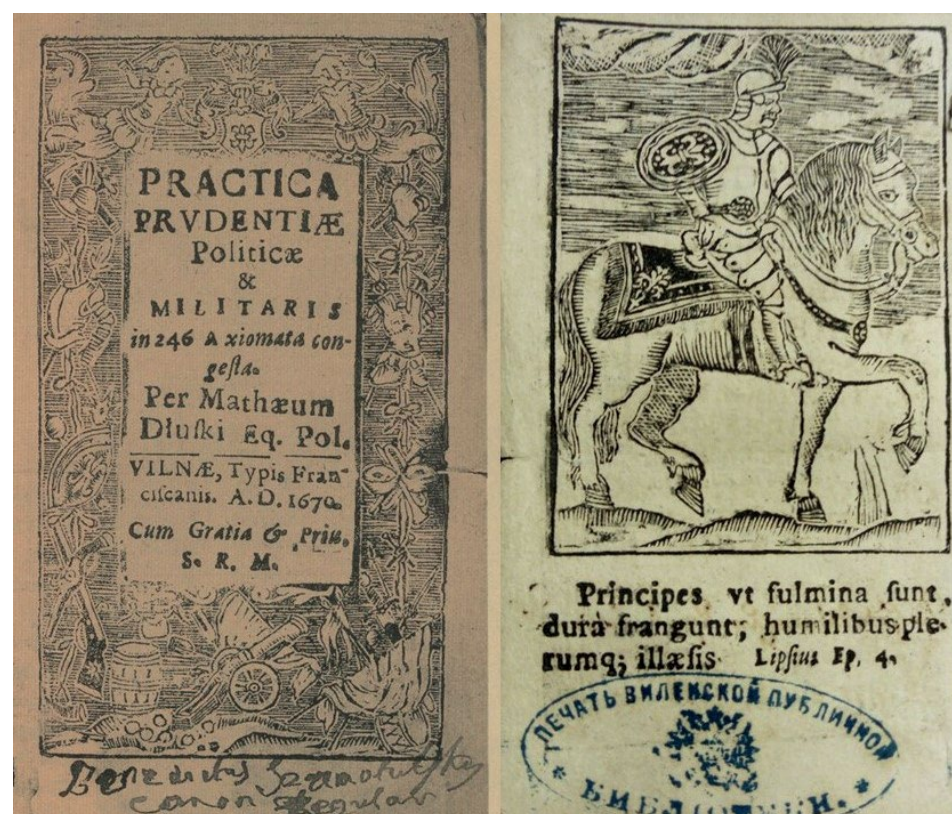

Principes vt fulmina fune Principes, vt fulmina fun
durà frangunt; humilibusple cumgi illxfis. Lipfius Ep. है włoskiej, produkowany głównie w Wenecji, który, zdarzało się, zamawiali też magnaci z Rzeczpospolitej ${ }^{43}$. Tkaninę herbową przedstawił Michelangelo Palloni we fresku Uczta Baltazara (1680-1685) w kościele w Pożajściu, co sugeruje, że taki wyrób miał również Krzysztof Zygmunt Pac ${ }^{44}$.

Nie sama jednak tkanina, identyfikująca godłem herbowym sportretowaną osobe, decyduje o randze wizerunku

z Antokola, a fakt, że jest on najpewniej kopią portretu namalowanego po bitwie pod Chocimiem w listopadzie 1673 r., w której Michał Kazimierz Pac odegrał ważną rolę jako wódz wojsk litewskich. To właśnie przetworzony widok naddniestrzańskiej twierdzy oddano po prawej stronie kompozycji. W ikonografii chocimskiej obowiązkowo pojawial się Jan Sobieski, któremu bitwa utorowała drogę do korony. Rzadkim przykładem, kiedy ukazano także Michała Kazimierza Paca, jest grafika dołączona do wierszowanego panegiryku, dedykowanego obu hetmanom litewskim przez autora Jacoba Benneta, wywodzącego się ze

3 Więcej na ten temat zob. m.in. M. Piwocka, O tkaninach, które zdobią i znacza, w: Tekstylia w zbiorach sakralnych. Inwentaryzacja - konserwacja - przechowywanie, red. H. Hryszko, A. Kwaśnik-Gliw

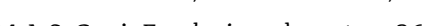

13. M. Dłuski, Practica prudentiae politicae et militaris in 246 axiomata congesta..., Wilno 1670. Fot. Biblioteka Uniwersytecka w Wilnie

szkockiej rodziny osiadłej w Wilnie (il. 12). Na rycinie Michał Kazimierz Pac konno, $\mathrm{z}$ wyciągniętą przed siebie buławą, w towarzystwie dwóch adiutantów prowadzi wojska litewskie do ataku ${ }^{45}$. Za nim jedna $\mathrm{z}$ chorągwi ozdobiona została godłem Gozdawa ${ }^{46}$.

Według Mieczysława Gębarowicza, który badał dorobek Wawrzyńca Krzczonowicza, twórcy omawianego miedziorytu, rola wojsk litewskich została na grafice wyolbrzymiona. Nie można jednak nie zauważyć, że stało się tak ze względu na podporządkowanie ryciny funkcji, wspót-

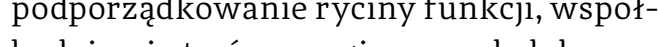
buduace utwor paneginy dedykowany Pacowii Radziwillowi, dwóm hetmanom litewskim. Mimo ewidentnych braków arty-
stycznych, dzięki przekonującej sile ilustrastycznych, dzięki przekonującej sile ilus
cyjnej miedzioryt stał się podstawą dla znanej i szeroko rozpowszechnianej ryciny Johanna Bensheimera ${ }^{47}$.

Triumfalny powrót Michała Kazimierza Paca z kampanii chocimskiej, w który wpisuje się antokolski portret, wiązał się także z przekazaniem do kościoła pw. św. św. Piotra i Pawła wojennych

45 J. Bennet, Virtus dexterae domini in virtute Polonorum Lituanorumq(ue) ostensa atque illustrissimo [...] Michaeli Casimerio Pac .... et tilustrissimo ac excellentisEgzemplarz z grafiką znajduje się jedynie w Vilniaus universiteto biblioteka (sygn. III 14495), co stanowi stan I miedziorytu. Stan I przechowuje także Muzeun Narodowe w Warszawie (sygn. Gr. Pol. 4129),

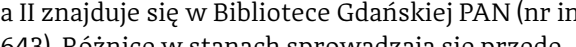
wszystkim do rozbudowy militarnego watku

związanego z przestawieniem Michała Kazimierza Radziwiłła oraz do braku sygnatury. M. Gębarowicz, Wawrzyniec - Laurenty Krzczonowicz. Nieznany
sztycharz drugiej potowy XVII wieku, „Folia Historiae sztycharz drugiej potowy X

$6 \mathrm{~W}$ tej samej grupie wojsk prezentowana jest Wiśniowieckiego, ówczesnego hetmana polne koronnego. W lewej górnej części kompozycii znajduje się chorągiew $\mathrm{z}$ herbem Radziwiłłów, a po 47 M. Gębarowicz, dz. cyt., s. 53, 58, 65-73; J. Talbierska, trofeów i jednocześnie wotów: dwóch litaurów (zachowane), tureckich sztandarów itkanin. W $1675 \mathrm{r}$. hetman doprowadził również do chrztu poimanych Turków, a do walki stoczonej w obronie Rzeczpospolitej i Kościoła odnoszą się motywy tureckie występujące w stiukowych panopliach, zdobiących świątynię kanoników regularnych laterańskich, oraz postaci świętych rycerzy patronujących wiktorii: Marcina, Maura oraz Jerzego ${ }^{48}$. Całopostaciowy portret $\mathrm{z}$ widokiem na bitwę pod Chocimiem uzupełnia więc wątek treściowy świątyni antokolskiej jako wotum za zwycięstwa Mic Kazimierza Paca za zw weiestwa Micha Do najbardziej cenionych portretów reprezentacyjnych, dalece przewyższajacych rangą ideową heroizację czy gloryfikację prezentowanej osoby przez jej wyobrażenie w zbroi lub przywołanie w tle sukcesu bitewnego, zaliczyć bez wątpienia trzeba portrety konne. Nie wiadomo, czy konterfekt tego typu Michał Kazimierz Pac posiadał, ale w drugiej połowie XVII w. wzeczpospolitej takie precedensy posr w Rzeczpospolitej takie ponsy poś wizerunków hetmańskich istniały ${ }^{49}$. tym, że chętnie eksponujący swe militarne zwycięstwa Pac, którego panegiryści określali jako nieustraszonego pogromcę Moskali i Turków, skorzystał z możliwości perswazyjnych takiego ujęcia ikonograficznego, świadczy drzeworyt umieszczony na rewersie frontyspisu dzieła Practica prudentiae politicae et militaris in 246 axiomata .

48 A.S. Czyż, Kościót.., dz. cyt., s. 205, 214, 217. 49 Była to grafika wykonana przez Jacopa Laura, ukazująca konnego Jana Zamoyskiego jako triumfujecego, stawiąca jego dokonania dzięki protekcc) w ten sposób był hetman Janusz Radziwiłł, dla którego w 1653 r. wybito medal przedstawiający go, gdy jako wojewoda wileński wjeżdża do stolicy Wielkiego Księstwa Litewskiego. M. Morka

so Autor sin siebie określit w tytule szlachcicen
Ramę frontyspisu tworzą zwisy wiązkami antykizowanych panoplii, na tóre składa się także tarcza z herbem Gozdawa i wyobrażoną przy niej buławą. Herb w wersji pełnej, z hełmem i klejnotem, zaprezentowano w zwieńczeniu kompozycji. Podtrzymują go dwie zbrojne postaci, których dolne partie ciała przechodzą w sploty roślinne, jedna z nich trzyma szablę, druga buławę. W dolnej części kompozycji znajdują się swobodnie rozmieszczone siedemnastowieczne militaria, $\mathrm{w}$ tym beczka prochu, strzelba i pistolet $\mathrm{z}$ torbą na naboje, armata wraz z kulami i ładownicami, szabla, pika, chorągwie, taraban i róg.

Tak zaprojektowana drzeworytnicza rama nie tylko odwołuje się do tematyki podejmowanej w książce, ale wskazuje, komu jest dedykowana stanowiąc komentarz do

polskim, a w krótkim panegiryku skierowanym do Michała Kazimierza Paca nazwał siebie „devotissiprudentiae politicae et militaris in 246 axiomata congesta..., Vilnae 1670, s. 1, 8. Jest to niewielkiego formatu, rzadko występujący druk, liczący ponad 300 stron. W wersji petnej, , frontyspisem dedykojedynie wich zbiorach Kizimierzowi Pacowi, znajduje sie (sygn. III 280). Widnieja na nim oznaczenia własnościowe proboszcza kościoła pw. św. šw. Piotra i Pawła na Antokolu Benedykta Szamotulskiego (jeden na wyklejce przedniej okładki, drugi w dolnej części

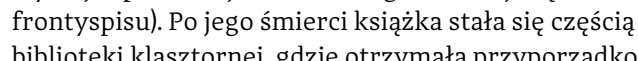
wanie (E III) zaznaczone na grzbiecie skórzaozą oprawy. Na kolejnej kracie, gdzie rozpoczyna sie dedykacja dla Michała Kazimierza Paca, inną rękąa wykonano podpis: ,Pro Con(ven)tu Vilnen(se) Can(onicorum) Regul(arium) Lateran(ensium)" (s. 3). WXIX w. ksiazzka znalazła się w Wilenskieje Bibliotece
Publicznej (wkleika). Omawiana publikacia Mateusza Dłuskiego jest edycja druga. Pierwsza ukazała sie w Zamościu w 1644 r. dzięki Franciszkowi Myszkowskiemu, kasztelanowi bełzkiemu, i miała inny frontyspis. Jest ona równie rzadka, a jej egzemplarz znajduje się W Zakładzie Narodowym im. Ossoliń-
skich (sygn. XVII-5211-I: XVII-374-I) Analizs. frontyspis został odnotowany w: I. Liškkevičienè, XVI-XVIII amžiaus knygu grafika: herbai senuosiuose lietuvos spadiniuose, Vilnius 1998, s. 89, 209, gdzie autorka identyfikuje jeźdźca z Michałem Kazimie- 


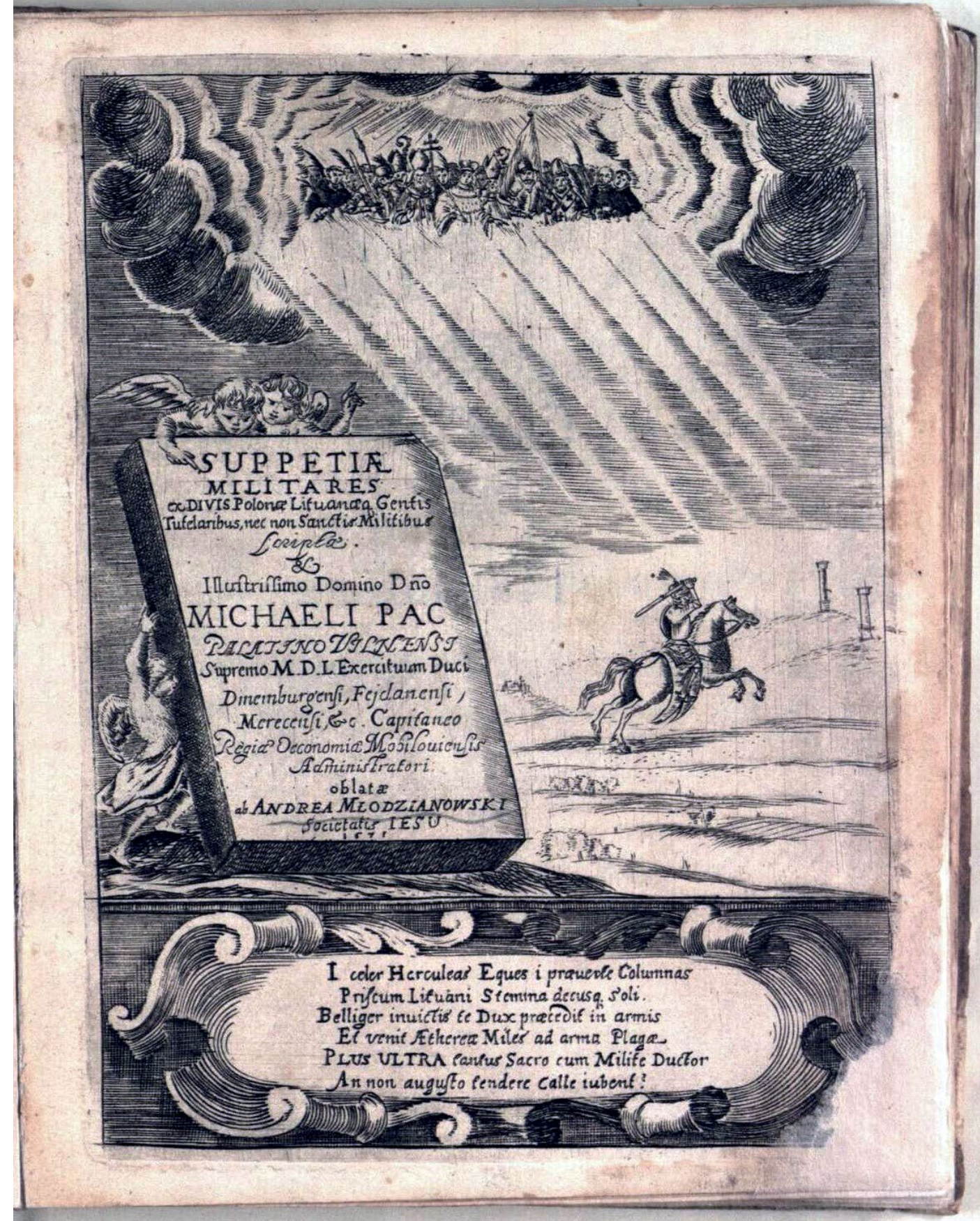

14. Frontyspis dzieła Suppetiae militares ex Divis Poloniae

Lituanaeq(ue)gentis tutelaribus nec non Sanctis Militibus scriptae...

Wilno 1671. Fot. Biblioteka Uniwersytecka w Wilnie wizerunku umieszczonego na odwrociu frontyspisu. Na portrecie przedstawiono mężczyznę o sumiastych wąsach lekko obróconego do widza, w pełnej pły towej zbro na ujętym z profilu koniu idącym stępa. W prawej dłoni postać dzierży buławę, a na ramieniu trzyma tarczę z Gozdawą. Wizerunek umieszczono na umownie zarysowanym pejzażu z obłokami.

W bardzo nieudolnie ciętym drzeworycie nie sposób odszukać podobienstwa twarzy jeźdźca z obliczem Michała Kazimierza Paca, choć nie ulega wątpliwości, że to on mia być w nim rozpoznawany, ci, ze to on mi, być w nim rozpoznawany, ale raczej z Gozdawy war stych wąsów. Na ża nostawic pytanie, czy mógł istnieć malarski konn portret hetmana. Nie sposób kwestii tej w sposób jednoznaczny rozstrzygnąć, wszak wzorcem dla tej grafiki mogły stać się przedstawienia innych jeźdźców. Rycinę opatrzono przeredagowanym cytatem z twórczości niderlandzkiego filozofa i historyka, Justusa Lipsiusza: Principes ut fulmina fulming plerumg(ue) no słowno-wizualną kompozycję o jednoznacznie panegirycznym i propagandowy charakterze, a przy tym niepozbawioną funkcji perswazyjnych, jako że zapowiadała ona dedykację poświęconą Pacowi opisywanemu, jako ozdobiony cnotami „dux sapientissimus" s2 odnoszący sukcesy na niwie Marsa i Pallady.

Należy podkreślić, że wybór profilowego ujęcia ma nie tylko swoje odniesienia tradycji antycznych portretów konnych na monetach, ale też wiąże się z pomnikowym charakterem, jaki nadano temu przedstawieniu. Stęp, jako najwolniejszy chód konia, był stosowany podczas uroczystych wjazdów, co zdaje się uchwycono na omawianym

51 Cytat winien brzmieć: , Reges ut fulmina sunt, dura frangunt, mollibus plerumque illafis" (Ep 4 . 52 M. Dłuski, dz. cyt., s. 6 drzeworycie. Takie ujęcie pozwalało wzmocnić oficjalny wizerunek hetmana, jako idealnego przywódcy $y^{53}$,którego panegiryści nieprzypadkowo okr ́bli jakopacifis

Dwustronną kartę tytułową książki Mateusza Dłuskiego należy zestawić $\mathrm{z}$ antykizującym frontyspisem dzieła Suppetiae militares ex Divis Poloniae Lituanaeq(ue) gentis tutelaribus nec non Sanctis Militibus scriptae jezuity Andrzeja Młodzianowskiego z 1671 r. (il. 14), które również dedykowano Michałowi Kazimierzowi Pacowiss. Antykizujący frontyspis składa się z trzech niejako oddzielnie ksztaltowanych scen Po

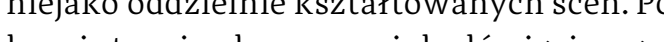
lewej stron kamienną tabicę z tytulem wydawnictwa. Przysiadły za nią dwa putta, z ktorych je no wskazuje na tytuł, a drugie na niebo, gdzie wśród obłoków unoszą się święci i patronowie państwa polsko-litewskiego (m.in. Kazimierz, Wojciech, Stanisław, Florian, Jacek, Wacław, Jozafat). Poniżej, po prawej stronie, ku dwóm kolumnom na horyzoncie pedzi na wspiętym koniu rycerz w pełnej zbroi. W prawej ręce dzierży miecz w pozyci bojowej, aw lewej tarczen Na hoc w pozycil bojowej, a wlewej tarczę. Na horyzoncie po lewej stronie widac zarys miasta. Pejzaz potraktowano schematycznie, zaznaczając jednak kolejne nieregularne tarasy, a także drzewa. Na dole frontyspisu w wolutowej i światłocieniowej ramie znajduje się wierszowana dedykacja:

„I celer Herculeas Eques i praeverte Columnas

Priscum Lituani Stemma decusg(ue) soli. Belliger invictis te Dux praecedit in armis Et venit Aetherea Miles ad arma Plagae. PLUS ULTRA tantus Sacro cum Milite Ductor An non augusto tendere Calle iubent?". olita Liškevičienè interpretuje jeźdźca $\mathrm{z}$ frontyspisu jako aluzję do herbu Litwy

53 M. Morka, dz.cyt. s. $14-23,34-35,38,41,79$

54 A.S. Czyż, Kościót..., dz. cyt., s. 184.

55 Grafika odnotowana w: J. Liškevicicienè, XVI-XVIII. dz. cyt., s. 79 . 
- Pogoń (Vytis). W połączeniu z treścią dedykacji oraz wstępem skierowanym do Michała Kazimierza Paca w zbrojnej postac widzieć można też alegoryczny wizerunek hetmana, stojącego na czele armii litewskiej i prowadzący ją do zwycięstwa. W trudach walki wspierają go święci o czym przypomniano w dedykacji. Ukazano ich, gdy swym blaskiem-ochroną otaczają jeźdźca. Dwie kolumny, ku którym zdąża hetman, są aluzją do Słupów

Herkulesa, które opatrywano zwyczajowo sentencją Plus Ultra (tu pominięta), co interpretowano nie tylko w kontekście przekra prania grani czania granic topgra literackie czy tez plastyczne shupow

Herkulesa było zachętą do podejmowania walki z wszelkimi ograniczeniami, co miało przynieść zasłużoną sławę i pamięć potomnych, ale także pomagało uzyskać symbiozę cnót. Herkules był też symbolem walki z wrogami Kościoła i zdobywania dla niego nowych światów ${ }^{36}$. Na takiego bohatera kreował się Michał Kazimierz Pac, hatéa knywany przez panegirystón Pac, porównywany przez par Kazitologicznego herosa, ktory walczy nie ty z wrogami ciała, ale i duszy, nie tylko z przeciwnikami Ojczyzny, ale i Kościoła ${ }^{57}$ Przy tym aspekt militarno-heroiczny, gwarantujący wieczną sławę silniej podkreślał wizerunki jeźdźców na wspiętych rumakach niż idących stępa ${ }^{58}$.

Przegląd ikonografii Michał Kazimierza Paca z jednej strony wskazuje na podejmowanie sprawdzonych działań

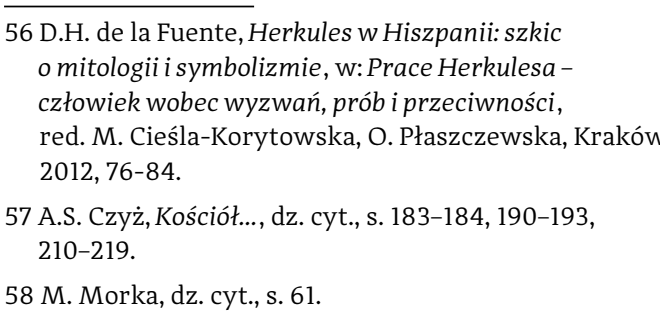

w zakresie autokreacji poprzez wizerunki eksponujące dzierzone urzẹdy, którym nierzadko dodawano także treści odnoszące się do przymiotów portretowanego bohater. W przypado ra. W prypadku Paca esponowano wyłącznie jego zołnierską posługę, pomijając senatorskie urzędy wojewody i kasztelana wileńskiego, które, choć prestiżowe, ustę powały miejsca chwalebnym czynom hetmańskim na polu Marsowym. Brakuje też w ikonografii Michała Kazimierza Paca wizerunków nieoficjalnych, a także zbiorowych, nie licząc fresków z Pożajścia, mimo że znano je w sztuce państwa polsko-litewske zno je w sz fakce parstwa polsk-litewse nigdy nie zazy on rodziny, calyctym ze nigdy nie założył on rodziny, całe życie poświęcając kolejnym kampaniom bitewnym oraz budowie kościoła pw. św. św. Piotra i Pawła na Antokolu w Wilnie, który miał się stać jego pomnikiem.

Wizualna propaganda własnej osoby pojawiła się po uzyskaniu przez Paca buławy polnej, która okazała się wstępem do kolejnych zaszczytów. Wybrany schemat kompozycyjny skodyfikowany przez niezachowany całopostaciowy portret autorstwa Daniela Schulza został w kolejnych latach wzbogacony o elementy zbroi. Schematy te powtarzano później wielokrotnie, rozbudowując rekwizyty hetmańskiego urzędu i wojenny sztafaż, tak jak w portrecie z kościoła antokolskiego. Za wyjątkowy i wczesny przykład należy uznać graficzne konne przedstawienie hetmana.

\section{STRESZCZENIE}

WIZERUNKI MICHAŁA KAZIMIERZA PACA - PRZEGLĄD IKONOGRAFII HETMANA

WTEWSKIEGO I WOJEWODY

WILEŃSKIEGO

W artykule zebrano i omówiono portrety Michała Kazimierza Paca, hetmana wielkiego litewskiego i wojewody wileńskiego, jednej ze znamienitszych postaci swoich czasów. Wizerunki Paca nie doczekały się do tej pory szerszych omówień. W artykule ukazano je w kontekście awansów na kolejne urzedy, co wymagało podjęcia szeregu ne urzędy co wy dzię scią byly tez hey $z$ a zan genealogicznych. Wartykule omówiono całą znaną ikonografię hetmana, a takż wzajemne zależności pomiędzy portretam

\section{SUMMARY}

PORTRAITS OF MICHAL KAZIMIERZ PAC - A REVIEW OF THE ICONOGRAPHY OF THE LITHUANIAN HETMAN AND VILNIAN VOIVODE

The article deals with the little-known portraits of Michał Kazimierz Pac. They demo strate that he did take proven self-aggrandizement measures used by others to portray themselves as public figures and as individual full of virtues. However, Pac concentrated on his soldierly service, disregarding his offices of the Vilnian voivode, possibly because he considered them prestigious but not so huch important as his laud inportant as is laudablehetmanly deeds on the battlefield. Also, there are no private or collective portraits of Michał Kazimierz Pac in his iconography, other than the frescos from the church in Pożajście, although these forms of artistic communication were known and used in the Polish and Lithuanian

Commonwealth. The most likely explanation of these two "gaps" is that Pac never married and devoted whole his life to the military career and to the building of the ch ro ha reer and to the building of the church under the invocation of St. Peter and St. Paul Antokol in Vilnius as his monument.
Pac took care of his promotion after earning the field baton, which event started his further career. The compositional scheme he chose, codified by the lost full-body portrait by Daniel Schulz, was augmented in time by the addition of pieces of armor. This pattern was later repeated a number of times, growing in new attributes of the hetman's office and in military staffage, as seen in the portrait from the Antokol church. The equestrian portrait (woodcut) of the hetman is an outstanding and early milestone in the formation of his public image.

\section{SLOWA KLUCZOWE}

Michał Kazimierz Pac, portret XVII-XVIII

w., Wielkie Księstwo Litewskie

\section{KEYWORDS}

ichał Kazimierz Pac, portrait of 17-18 C., Grand Duchy of Lithuani 


\section{BIBLIOGRAFIA}

\section{Źródła archiwalne}

Archivio di Stato di Firenze sygn. 4492 (List Lorenza Domenica de'Pazziego do Kosmy III, Kraków 22 II 1676 r.), k. 294.

Vilniaus Universiteto Bibliotek of 4 (A566) 24174 (Inwentarz pałacu Paców, $1813 \mathrm{r}$. .

\section{Źródła drukowane}

Bennet J., Virtus dexterae domini in virtute Polonorum Lituanorumq(ue)ostens atque illustrissimo [ ] Michael Casimiro Pac [ ]et illustrissimo ac exCasimiro Pac [.] cellentissimo [...] Michaeic

Bobiatyński K., Nagielski M., Testamenty Michała Kazimierza Paca i Aleksandra Hilarego Połubińskiego w przededniu kampanii na Ukrainie przeciwko Turkom i Tatarom w 1675 roku, "Materiały do Historii Wojskowości", t. 3, 2006, cz. 1, S. 130-143.

Dłuski $M$. Practica prudentiae politicae et militaris in 246 axiomata congesta. Vilnae 1670.

Małachowski A., Kwitnaca po śmierciś. $P$. [...] Michała Kazimierza Paca [...] pamięc przy dorocznych exequiach, w kollegiacie SS. Apostołów Piotra i Pawła [...] na Antokolu..., Wilno 1686.

Okolski S., Orbis Poloni..., t. 2, Kraków 1643. Paprocki B., Gniazdo cnoty, skad herby rycerstwa sławnego [...] początek swój maja Kraków 1578.

Priorato G.G., Historia di Leopoldo Cesare..., t. 3, Vienna 1674.

Zielejewicz E., Wojna z słońcem [...] Krzysztofa Odachowskiego [...]na kazaniu pogrzebowym, [b.m.] [1663].
Bartyś J., Działalność gospodarcza i społeczna generała Ludwika Paca w dobrach Dowspuda na Suwalszczyźnie w latach 1815-1830, ,Rocznik Białostocki”, r. 9, 1970, s. $35-83$

Bernatowicz T Mitra i buława. Królewskie ambicje ksiażąt w sztuce

Rzeczpospolitej szlacheckiej (1697-1763), Warszawa 2011.

Bobiatyński K., Michał Kazimierz Pac - wojewoda wileński, hetman wielki litewski. Działalność polityczno-wojskowa, Warszawa 2008.

Chojecka E.,Portret polski XVII i XVIII wieku. Katalog wystawy. Galeria BWA Katowice maj-czerwiec 1978, Katowice 1978

Czyż A.S., Kościół świętych Piotra i Pawła na Antokolu w Wilnie, WrocławWarszawa-Kraków 2008.

Czyż A.S., Fundacje artystyczne rodziny Paców: Stefana, Krzysztofa Zygmunta i Mikołaja Stefana Paców. „Lilium bonae spei ab antiquitate consecratum", Warszawa 2016.

Czyż A.S., Przekaz symboliczny i propagandowy programów heraldycznych w siedemnastowiecznych żałobnych drukach Pacowskich, czyli „Liliaci” i ich Gozdawa, „Przegląd Wschodni”, t. 14, 2018, z. 4 (56), s. 739-765.

Fabiani B., Nieznane portrety Paców. Studium biograficzno-ikonograficzne z XVII w. "Roczniki Muzeum Narodowego", r. 15, 1971, nr 2, s. 137-180.

Fuente de la D. H. Herkules w Hiszpanii: szkic o mitologii i symbolizmie, w: Prace Herkulesa - człowiek wobec wyzwan prób i przeciwności, red. M. Cieśla Korytowska, O. Płaszczewska, Kraków 2012, s. 75-86.

Gębarowicz M., Wawrzyniec - Laurenty Krzczonowicz. Nieznany sztycharz drugiej połowy XVII wieku, Folia

Historiae Artium", t. 17, 1981, s. 49-120.
Jakubowski T., Grafika. Portrety. Katalog zbiorów. Zamek Królewski

w Warszawie - Muzeum Fundacja Zbiorów im. Ciechanowieckich Warszawa 2017.

Kałamajska-Saeed M., Genealogia przez obrazy. Barokowa ikonografia rodu Sapiehów na tle staropolskich galer portretowych, Warszawa 2006

Kałamajska-Saeed M.,Portrety z galerii nieświeskiej w akwarelach Karola Raczyńskiego, w: Studia nad sztuka renesansu i baroku, red. J. Lileyko, I. Rolska-Boruch, t. 5, Lublin 2004, s. 305-362.

Katalog portretów osobistości polskich i obcych w Polsce działajacych, red. H. Widacka, t. 4, Warszawa 1994 t. 7, Warszawa 1999.

Katalog zabytków sztuki w Polsce, t. 4: Miasto Kraków, cz. 4: Kazimierz i Stradom. Kościoły i klasztory, 1, red. I. RejduchSamkowa, J. Samek, Warszawa 1987.

Klajumiené D XVIII a. sieny tapyba Lietuvos bažnyčiu architektūroje. Monografija, Vilnius 2004 .

Liškevičienė I Mundus emblematum: XVII a. Vilniaus spaudiniu ilustracijos, Vilnius 2005

Liškevičienė J., XVI-XVIII amžiaus knygu grafika: herbai senuosiuose lietuvos spadiniuose, Vilnius 1998.

Łoski J., Jan Sobieski, jego rodzina, towarzysze ni i współczesne zabytki, Warszawa 1883

Matušakaitè M., Portretas Lietuvos Didžiojoje Kunigaikštystëje, Vilnius 2010

Mizerniuk N.,Z dziejów galerii rodowej Ludwika Paca w pałacu w Dospudzie, w: Władza i prestiż. Magnateria Rzeczpospolitej w XVI-XVIII wieku, red. J. Urwanowicz, Białystok 2003, s. $661-678$.
Mizerniuk-Rotkiewicz N., Muzeum Starożytności w Wilnie. Historia i rekonstrukcja zbiorów malarstwa i grafiki, Warszawa-Toruń 2016

Morelowski M., Gobeliny wileńskie. Ich pochodzenie, wartość i losy, Wilno 1933.

Morka M.,Polski nowożytny portret konnyijego europejska geneza, WrocławWarszawa-Kraków-Gdańsk-Łódź 1986

Narodziny stolicy. Warszawa w latach 1596 668 , red. P. Mrozowski, $M$. Wrede, Warszawa 1996.

Pasierb J.S., Janocha M., Polonica artystyczne w zbiorach watykańskich, Warszawa 2002.

Petrus T., Karpowicz T., Portrety osobistości dawnej Rzeczpospolitej w zbiorach mińskich. Katalog wystawy, Kraków 1991.

., O tkaninach, które zdobia i znaczo w: Tekstylia w zbiorach sakralnych. Inwentaryzacja-konserwacja-przechowywanie, red. H. Hryszko, A. KwaśnikGliwińska, M. Stachurska, Warszawa 2013, S. 154-162, 370-373.

Ruszczycówna J., Portret polski XVII-XVIII w. ze zbiorów Muzeum Narodowego w Warszawie, Biała Podlaska 1980.

Šinkūnaitè L., XVII a. Lietuvos portretas, Vilnius 2000

Stankiewicz A., Tradycje militarne Chodkiewiczów w świetle grafiki oraz stemmat w drukach ulotnych z pierwszej połowy XVII w., w: Studia nad staropolską sztuka wojenna, red. Z. Hundert, K. Żojdź, J.J. Sowa, t. 3, Oświęcim 2014, s. 61-93.

Steinborn B., Malarz Daniel Schultz. Gdańszczanin w służbie królów polskich, Warszawa 2004

Talbierska J., Grafika XVII wieku w Polsce. Funkcje, ośrodki, artyści, dzieła Warszawa 2011.

Vaišvilaitè I.,Baroko pradižia Lietuvoje, Vilnius 1995. 